\title{
The influence of environmental condition on the creation of organic compounds in Pinus sylvestris L. rhizosphere, roots and needles
}

\author{
Zuzanna Magdziak ${ }^{1}\left[\right.$ - Monika Gąsecka ${ }^{1} \cdot$ Bogusława Waliszewska $^{2} \cdot$ Magdalena Zborowska $^{2}$. \\ Andrzej Mocek ${ }^{3}$. Wojciech J. Cichy ${ }^{4} \cdot$ Bartłomiej Mazela $^{2} \cdot$ Tomisław Kozubik $^{1}$ - Agnieszka Mocek-Płóciniak ${ }^{5}$. \\ Przemysław Niedzielski ${ }^{6}$. Piotr Goliński ${ }^{1} \cdot$ Mirosław Mleczek ${ }^{1}$
}

Received: 28 June 2019 / Accepted: 6 October 2020 / Published online: 19 October 2020

(c) The Author(s) 2020

\begin{abstract}
Key message Studied organic molecules in Pinus sylvestris L. seem to have acted as a safety net for metal transport, chelation and sequestration, allowing adaptation and growth under highly polluted conditions.

Abstract Pinus sylvestris L. is known for its ability to survive in areas of highly elevated metal pollution, such as flotation tailings. The aim of the study was to estimate the content of selected organic molecules (including aliphatic low molecular weight organic acids (ALMWOAs), phenolic compounds and terpenes) and the physiological mechanisms underlying differences in metal/metalloid tolerance of $P$. sylvestris growing in unpolluted (soil) and polluted (flotation tailings) areas. The dominant ALMWOAs in rhizosphere soil extracts were citric acid followed by malic and oxalic acids, whereas in flotation tailings malic and oxalic acids. In roots and needles, the content of ALMOWAs was significantly higher in P. sylvestris L. tissue from flotation tailings in comparison to soil. Phenolic compounds were detected only in roots and needles, with a generally higher content of nearly all detected compounds from flotation tailings. The composition of roots did not contain all the compounds detected in needles. The profile of needles additionally contained four hydroxybenzoic, protocatechuic and salicylic acids. In pine needles, 24 volatile terpenes were identified in total. The content of these compounds in pine needles from the polluted area was markedly different from the unpolluted area. The dominant volatile monoterpenes in $P$. sylvestris L. needles from the unpolluted area was three carene, while in pine needles from the polluted area monoterpenes $\alpha$-pinene was dominant.
\end{abstract}

Keywords Aliphatic low molecular weight organic acids $\cdot$ Phenolic compounds $\cdot$ Terpenes $\cdot$ Flotation tailings $\cdot$ Metal phytoextraction

Communicated by E. Magel .

Zuzanna Magdziak

zuzanna.magdziak@up.poznan.pl; zuza@positiv.pl

1 Department of Chemistry, Poznań University of Life Sciences, Wojska Polskiego 75, 60-625 Poznań, Poland

2 Institute of Chemical Wood Technology, University of Life Sciences in Poznań, Wojska Polskiego 38/42, 60-637 Poznań, Poland

3 Department of Soil Science and Land Protection, University of Life Sciences in Poznań, Szydłowska 50, 60-656 Poznań, Poland

\section{Introduction}

Soil contamination with toxic trace elements is widespread and has a significant impact on such specific ecosystem functions as found in soil (Huang et al. 2016). It is particularly

4 Wood Technology Institute, Winiarska 1, 60-654 Poznań, Poland

5 Department of General and Environmental Microbiology, University of Life Sciences in Poznań, Szydłowska 50, 60-656 Poznań, Poland

6 Faculty of Chemistry, Adam Mickiewicz University in Poznań, Umultowska 89B, 61-614 Poznań, Poland 
associated with anthropogenic activities which currently pose a serious problem for ecological equilibrium, adversely affecting the maintenance of environments and proving destructive for flora and fauna (Rocha et al. 2016). Several species of woody plants, such as Salix and Populus (Tlustoš et al. 2007; Vamerali et al. 2009; Mleczek et al. 2018), Quercus robur L. and Acer platanoides L. (Budzyńska et al. 2017a), Ulmus laevis Pall (Budzyńska et al. 2017b) and Betula pendula Roth. (Mleczek et al. 2016), have been shown to have a high potential for phytoextraction, uptake and accumulation of metals present in the soil matrix and can be a suitable choice for dendroremediation of extremely polluted areas. Pinus sylvestris L. (P. sylvestris) is a common woody species that can be used for restoring degraded soil ecosystems because of its adaptive capabilities (Placek et al. 2016). According to Mleczek et al. (2018), P. sylvestris may survive in areas with high levels of metal pollution, such as flotation tailings. In studied specimens of $P$. sylvestris originating from polluted areas a significantly lower rate of phytoextration of selected elements was recorded in comparison with unpolluted areas (Mleczek et al. 2018). Nevertheless, the $P$. sylvestris was able to survive, grow and develop. Differences in biomass and phytoextraction ability clearly demonstrate the influence of environmental conditions of growth, but at the same time indicate the importance of physiological changes in the studied plants. In the light of the diverse potential of the studied plants and limited literature data on the creation and exudation by woody plant roots of different organic compounds (aliphatic low molecular weight organic acids (ALMWOAs), enzymes, amino acids, phenolic compounds, simple and complex sugars, vitamins, purines, proteins and flavonoids) into the rhizosphere (Ryan et al. 2001; Adeleke et al. 2017; Magdziak et al. 2017), we investigated the effects of flotation tailings in organic biomolecule activity in the rhizosphere. The rhizosphere is the most important soil zone, where fundamental processes occur that are responsible for plant functioning. Any change in the soil chemistry, including metal/metalloid concentration, can impact the cycling of carbon and other nutrients (Huang et al. 2016). The above molecules, especially ALMWOAs and phenolic compounds, are essential factors for nutrient acquisition (Dinh et al. 2017). They are present in the most abundance and are most reactive with metals (Koo et al. 2010); they play a role in alleviation of anaerobic stress in roots as well as mineral weathering (Adeleke et al. 2017). They additionally influence several soil processes, e.g. sorption and desorption (Wang et al. 2015), oxidation and reduction (Blaylock and James 1994) and precipitation and dissolution (Zhou et al. 2007). Moreover, in some of the previously mentioned studies, ALMWOAs and phenolic compounds have been found in plant tissues (mainly, roots and leaves) (Drzewiecka et al. 2017; Magdziak et al. 2017), where next to the rhizosphere, plants use ALMWOAs to transport, sequestrate and prevent cytoplasmic precipitation of toxic elements in cells, or in the case of phenolic compounds, in participation in adaptation and detoxification mechanisms mainly related to their structure and antioxidant properties (Ivanov et al. 2012; Jiang et al. 2017a, b; Benbettaieb et al. 2018).

Plant cells also produce many other groups of chemical compounds. Extractives include, e.g. essential oils, which are multicomponent mixtures of mono-, sesqui- and diterpene compounds or phenylpropane derivatives (phenolics). They take various forms: hydrocarbons, alcohols, aldehydes, ketones, esters or ethers. Furthermore, essential oils may contain sulfur and nitrogen substances of coumarins. The percentage shares of individual components vary and depend on many factors, i.e., plant ontogenesis, geographical region, growing and harvest conditions, storage method and preparation for further processing (Gonçalves et al. 2003; Silva et al. 2003; Dob et al. 2005; Bakkali et al. 2008; Gilles et al. 2010; Stefanakis et al. 2013).

It is known that the chemical composition of oils depends on many factors (Grochowski 1990; Głowacki 1994). Unfavorable growth conditions, such as soil or air pollutions lead to a biochemical tree response to stress (including changes in the composition of essential oils) (Chojnacki and Cichy 1995). However, up to now, no studies have been able to show a clear relationship between the composition of the oils and toxic metal at high content level in the substrate on which the trees grow (Kainulainen et al. 1992; Supuka and Berta 1998; Fuksman 2002).

More studies are necessary to understand the mechanisms triggered by woody plants. Among toxic metals described in literature data, cadmium $(\mathrm{Cd})$, lead $(\mathrm{Pb})$ and zinc $(\mathrm{Zn})$ are often presented as metal pollution stress which activates defense mechanisms related to changes in the creation and exudation of organic molecules. On the other hand, there is limited data on the response of woody species to their exposure to highly toxic elements, such as arsenic (As), mercury $(\mathrm{Hg})$ or thallium $(\mathrm{Tl})$.

For this reason, the present study extends the research carried out by Mleczek et al. (2018), where P. sylvestris trees were grown in soil and flotation tailings characterised by specific chemical properties. The aim of the study was to estimate the content of selected organic molecules and physiological mechanisms underlying differences in metal/metalloid tolerance in P. sylvestris growing on soil (unpolluted area) and extremely contaminated flotation tailings (polluted area). The investigation focused on an evaluation of changes in aliphatic ALMWOAs, phenolic compound content in the rhizosphere and/or roots, as well as ALMWOAs, phenolic compounds and terpenes in needles. Such a determination is essential to verify how organic molecules might influence an increase in bioavailability and the accumulation of metals/metalloids in P. sylvestris organs. The above molecules 
were chosen as biochemical parameters of plant reaction to elevated concentrations of toxic elements in flotation tailings due to their accumulation, chelation, regulation and translocation as a probable mechanism of their detoxication as well as an antioxidant function (Viehweger 2014; Dinh et al. 2017).

\section{Materials and methods}

\section{Characteristics of $P$. sylvestris L. specimens and area description}

The experimental materials were five specimens of 9-yearold $P$. sylvestris L. collected from two different experimental areas; an unpolluted area with soil characterised by an element concentration similar to the geochemical background of Polish soils and an area polluted by tailings from copper ore flotation processes. The trees had grown in Dystric Arenosols (unpolluted area); in a mixed forest in the Greater Poland province (mid-west region of Poland) and in Spolic Technosols (polluted area) in a flotation tailings disposal area in the Lower Silesian province (southwest region of Poland). They were not only characterised by similar height, but also by the size of their upper branches. From each experimental area five specimens of $P$. sylvestris $\mathrm{L}$. were collected and analyzed. A detailed description of this experiment and characteristics of the mineral composition of the experimental areas was published in our previous study (Mleczek et al. 2018).

\section{Sample collection}

In accordance with the method of Hammer and Keller (2002), the root zone from the unpolluted area (soil) and the polluted area (flotation tailings) was sampled from the surroundings of the P. sylvestris L. plant roots. Shaking and gentle cleansing by hand detached the soil attached to the roots. Samples of the root zone as well as soft roots (unheated) were separately preserved in polyethylene bags. Needles were collected from both the bottom and top of $P$. sylvestris L. trees and immediately placed in a portable refrigerator. Secured samples were then transported to the laboratory.

\section{Preparation of rhizosphere, roots and needle samples of $P$. sylvestris L. for ALMWOAs and phenolic compound analysis}

Environmental subsamples collected from the two significantly different environmental surfaces were carefully cleaned of the residue of roots and any other extraneous materials, homogenised, dried at room temperature, sieved by a nylon fibre sieve $(<1 \mathrm{~mm})$ and stored for subsequent analysis.

Roots were immersed in $0.01 \mathrm{M} \mathrm{HCl}$ cold solution in order to eliminate trace elements adsorbed at the root surface (Adeniji et al. 2010), washed with cold deionised water and gently dried on a filter paper to remove excess water. Samples of $P$. sylvestris L. roots and needles $(\sim 1.0 \mathrm{~g})$, ground to powder in a mortar chilled using liquid nitrogen were collected in $50 \mathrm{~mL}$ centrifuge tubes and stored frozen $\left(-80^{\circ} \mathrm{C}\right)$ until analysis. The extraction method for ALMWOAs and phenolic compounds analysis in all the studied matrices was presented in detail by Magdziak et al. (2017) and Gąsecka et al. (2017). The obtained solutions were evaporated to dryness and stored frozen $\left(-80^{\circ} \mathrm{C}\right)$ until analysis.

Samples prepared from the rhizosphere, roots and needles before HPLC analysis were dissolved in $1 \mathrm{~mL}$ of deionised water, centrifuged and filtered through filters of $0.22 \mu \mathrm{m}$ immediately prior to chromatographic analysis. For the determination of ALMWOAs and phenolic compounds $10 \mu \mathrm{L}$ of liquor was injected onto the HPLC column $\mathrm{C}_{18}$ according to the method presented by Magdziak et al. (2017) and UPLC phenolic compounds analyses as described by Gąsecka et al. (2017).

\section{Preparation of samples of $P$. sylvestris $\mathrm{L}$. needles for terpenes analysis}

Until analyses the needles were stored in a freezer at a temperature of $-18{ }^{\circ} \mathrm{C}$ after which they were cut manually to approx. 1-2 $\mathrm{mm}$ in length. Samples of $0.1 \mathrm{~g}$ were weighed and transferred to $15 \mathrm{~mL}$ glass vials equipped with a silicone-Teflon septum. In order to confirm the equilibrium of compounds in the headspace over the material each sample was subjected to a 10 -min preincubation at a temperature of $40{ }^{\circ} \mathrm{C}$ in a water bath.

Microextraction on CAR/PDMS (carboxen/polydimethylsiloxane) fibre was run after the needles were placed into the vial through the septum. Absorption lasted for $10 \mathrm{~min}$ and, similarly to preincubation, it was run at $40{ }^{\circ} \mathrm{C}$. Thermal desorption was run after the needles were introduced to the gas chromatograph injector heated to $230{ }^{\circ} \mathrm{C}$. Desorption time was 5 min.

The GC oven temperature was set at $50^{\circ} \mathrm{C}$ for 4 min and then programmed to $240{ }^{\circ} \mathrm{C}$ for $5 \mathrm{~min}$ at a rate of $10^{\circ} \mathrm{C} / \mathrm{min}$, using $\mathrm{He}$ as a carrier gas $(60 \mathrm{kPa})$. The injector and detector temperatures were maintained at $220^{\circ} \mathrm{C}$ and $250{ }^{\circ} \mathrm{C}$, respectively.

Volatile compounds from pine needles were analyzed by solid phase microextraction (SPME). The assay principle consists in the sorption of microscopic amounts of organic compounds in a thin, cylindrical layer of the stationary phase, which covers glass or quartz fibres. In analytical practice the headspace technique (HS-SPME) is most commonly 
applied, in which the fibre is placed in the headspace over the tested sample for a specific period of time, after which the fibre is placed within a needle. Sorption of volatile compounds depends on their affinity to the stationary phase. Silicone phases are the most frequently used group. The next stage consists in the desorption of the analyte to the gaseous phase which takes place after the fibre is placed in the injection port of a gas chromatograph (Lord and Pawliszyn 2000).

Chromatographic analysis was run in a GC/MS TRACE 1300 gas mass chromatograph (Thermo-Scientific) equipped with a DB 5 column $(30 \mathrm{~m} \times 0.25 \mathrm{~mm}$ i.d., film thickness $0.25 \mu \mathrm{m}$ ), a mass spectrometer with a single quadrupole and an ionization voltage of $70 \mathrm{eV}, \mathrm{m} / \mathrm{z}$ scan range 35-350 Da. Qualitative analysis was based on a comparison of retention times and indices with NIST mass spectra libraries and other corresponding data (Adams 2007). Quantities of individual VOC components were calculated as relative concentrations (peak area percentages).

\section{Statistical analysis}

Statistical analysis was done using STATISTICA 10 and consisted of ANOVA followed by the post hoc Tukey's test. For the comparison of values characterising the studied material from two independent areas, the significances $(* P<0.05, * * P<0.01, * * * P<0.001)$ between control and treated plants were determined using a Student's Test. Principal Component Analysis, PCA, was performed to present the relationships between independent variables (the content of separately ALMWOAs, phenolic compounds and terpenes). To determine if the average content of individual ALMWOAs and phenolic compounds in two variants: root vs needle on the bottom and root vs needle on the top are equal, a $t$ test with Welch correction for unequal variance ( $t$ test () in R) was used. These analyzes were performed independently for plants from unpolluted and polluted areas.

\section{Results}

\section{ALMWOAs and concentration of phenolic compounds in rhizosphere zone of $P$. sylvestris $\mathrm{L}$.}

Concentration of ALMWOAs was lower in the rhizosphere zone than in roots and needles (Table 1). The profile and concentration of acids were strictly dependent on the condition of $P$. sylvestris growth.

The total amount of identified organic acids in the rhizosphere zone of both soil and flotation tailings was almost the same. However, in the case of profile, the dominant acids in rhizosphere soil extracts from the unpolluted area were citric acid ( 41.9 $\mu \mathrm{g} \mathrm{kg}^{-1}$ dry weight (DW)) followed by malic and oxalic acids $\left(\sim 16.8\right.$ and $16.7 \mu \mathrm{g} \mathrm{kg}^{-1} \mathrm{DW}$, respectively), whereas from the flotation tailings root zone, malic and oxalic acids ( 35.6 and $46.2 \mu \mathrm{g} \mathrm{kg}^{-1} \mathrm{DW}$, respectively). The rest of the acids were found at lower concentration and fumaric acid in both root zones was below the limit of detection. Phenolic compounds in the rhizosphere of $P$. sylvestris L. were also below the detection limit.

\section{ALMWOAs content in roots and needles of $P$. sylvestris $\mathrm{L}$.}

Six ALMWOAs were identified in the root and needles extracts (acetic, citric, fumaric, malic, oxalic and succinic) of P. sylvestris L. plants. As shown in Table 1, the content of organic acids in the roots of pine had a tendency to increase. Among the detected acids, acetic, citric, malic and oxalic predominated in roots (Table 1). The amount of the aforementioned acids was significantly higher in P. sylvestris L. roots from flotation tailings in comparison to the unpolluted area. It should be noted that a significant increase was observed for citric and malic acids $(\sim 5.2$ and $\sim 8.5$ times

Table 1 Content $\left[\mathrm{\mu g} \mathrm{g}^{-1} \mathrm{DW}\right]$ of low molecular weight organic acids in Pinus sylvestris L. rhizosphere, roots and needles from the bottom and the top growing in two experimental areas

\begin{tabular}{|c|c|c|c|c|c|c|c|c|}
\hline \multirow[t]{2}{*}{ Acid } & \multicolumn{2}{|l|}{ Rhizosphere } & \multicolumn{2}{|l|}{ Root } & \multicolumn{2}{|c|}{ Needle on the bottom } & \multicolumn{2}{|c|}{ Needle on the top } \\
\hline & Unpolluted & Polluted & Unpolluted & Polluted & Unpolluted & Polluted & Unpolluted & Polluted \\
\hline Acetic & $2.51 \pm 0.31$ & $8.71 \pm 0.92 *$ & $71.9 \pm 7.50$ & $39.4 \pm 1.70 *$ & $62.6 \pm 8.06$ & $45.4 \pm 9.36$ & $94.6 \pm 6.05$ & $79.7 \pm 4.08 *$ \\
\hline Citric & $8.52 \pm 1.26$ & $41.9 \pm 3.60^{*}$ & $27.6 \pm 3.70$ & $142 \pm 8.90^{*}$ & $22.3 \pm 1.62$ & $80.4 \pm 9.48^{*}$ & $55.3 \pm 3.40$ & $195 \pm 19.3^{*}$ \\
\hline Fumaric & nd & nd & $4.4 \pm 0.13$ & nd & $10.2 \pm 0.20$ & $18.3 \pm 3.38 *$ & $17.1 \pm 1.16$ & $8.04 \pm 1.01 *$ \\
\hline Malic & $35.6 \pm 4.16$ & $16.8 \pm 2.28 *$ & $13.7 \pm 2.11$ & $166 \pm 15.3^{*}$ & $36.8 \pm 2.43$ & $213 \pm 9.25^{*}$ & $51.0 \pm 2.93$ & $59.9 \pm 8.11$ \\
\hline Malonic & $3.32 \pm 0.49$ & nd & nd & nd & nd & nd & nd & nd \\
\hline Oxalic & $46.2 \pm 2.52$ & $15.7 \pm 3.06^{*}$ & $35.4 \pm 1.77$ & $20.9 \pm 1.47 *$ & $68.0 \pm 2.81$ & $107 \pm 5.45^{*}$ & $98.2 \pm 4.27$ & $75.9 \pm 6.02 *$ \\
\hline Succinic & $1.39 \pm 0.08$ & nd & $0.86 \pm 0.05$ & $3.09 \pm 0.74^{*}$ & $26.8 \pm 1.69$ & $105 \pm 13.6^{*}$ & $5.83 \pm 0.12$ & $9.24 \pm 1.12 *$ \\
\hline Sume & $97.6 \pm 6.32$ & $83.1 \pm 2.43$ & $154 \pm 12.9$ & $371 \pm 15^{*}$ & $227 \pm 14.5$ & $569 \pm 19.9$ & $322 \pm 16.4$ & $427 \pm 26.0$ \\
\hline
\end{tabular}

$n d$ not detected, $n s$ not significant

$* P \leq 0.05$ 
more, respectively, in comparison to control plants from soil), while, particularly in the case of acetic and oxalic acids, the situation was opposite (reduction was observed more than $\sim 2$ and 1.6 times, respectively). Fumaric acid was present in roots from unpolluted soil, while in roots of trees from flotation tailings it was below the limit of detection. The sum of ALMWOAs content in fine root samples increased $\sim 2.4$ times for plants harvested from the polluted area.

The dominant ALMWOAs present in P. sylvestris L. needles from the bottom and top of the control plants were acetic and oxalic (Table 1). The content of these acids decreased in whole needles of pine trees grown in the polluted area in comparison with the control plants. The exception were needles collected from the bottom in pine growing on flotation tailings, where the content of oxalic acid increased almost $\sim 1.6$ times. In the P. sylvestris L. needles collected from flotation tailings, the dominant acids were citric, malic and succinic. However, their content exhibited several differences related especially to the height of needles (bottom or top) and the area conditions of growth and accounted for approximately $14-37 \%$ of the total acid content. A significant effect on the citric acid creation in the bottom and top needles was noted, where their content increased in needles sampled from $P$. sylvestris L. growing on flotation tailings (more than 3.5 times). In the case of malic and succinic acids, their content also increased significantly, but only in needles from the bottom ( $~ 5.9$ and $\sim 4$ times higher, respectively). The content of these acids in needles from the top increased slightly $(\sim 1.18$ and $\sim 1.8$, respectively). The lowest content of all the analyzed acids was observed for fumaric acid. In the case of needles collected from the bottom, its content increased in comparison to the control plants, where its content significantly decreased ( twofold) in needles collected from the top.

More, for a graphical presentation of the obtained results and relationships between ALMWOAs determined in roots and needles of plants collected from unpolluted and polluted areas, a Principal Component Analysis (PCA) was performed. In the analysis of ALMWOAs, $64.75 \%$ $(45.70+19.05)$ of variability was explained, what good reflects of observed relationships. PCA analysis allowed to show the high concentration of malonic acid in the rhizosphere of P. sylvestri from the unpolluted area (Fig. 1).
Fig. 1 Principal component analysis for low molecular weight organic acids contents in rhizosphere and studied Pinus sylvestris L. organs ( $U$ Unpolluted, $P$ Polluted). ALMWOAs: 1-acetic; 2-citric; 3-fumaric; 4-malic; 5-malonic; 6oxalic; 7-succinic; 8-sum

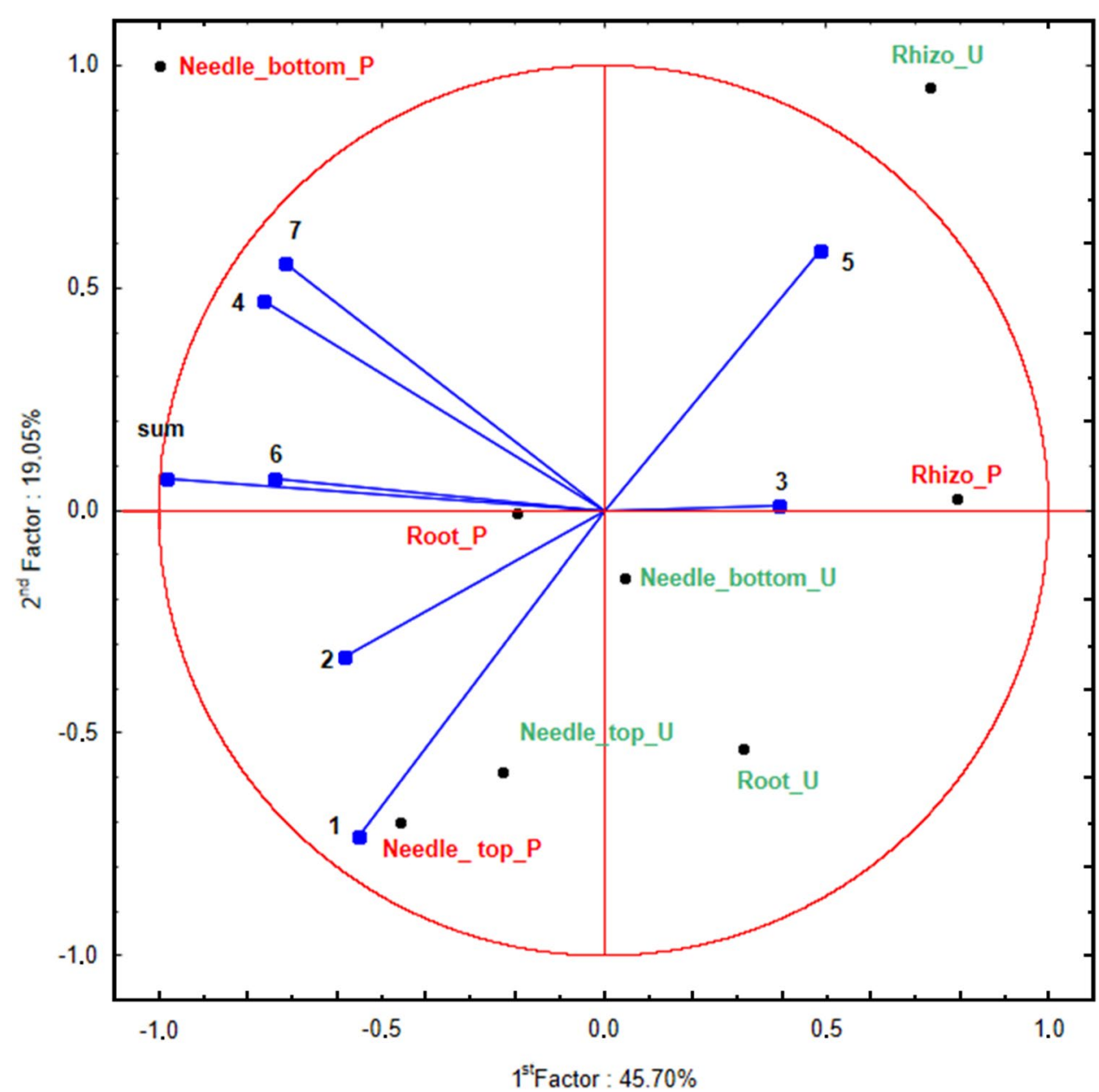


Moreover, the higher content of malonic, succinic and sum of ALMWOAs in needles on the bottom and needles on the top, than in the same tissues of $P$. silvestris collected from the unpolluted area was observed. It is worth to underline a high content of citric acid in roots of plants from polluted than the unpolluted area was also recorded.

Table 2 Characteristics of differences between content of aliphatic low molecular weight organic acids in roots and needles separately for plants collected from unpolluted and polluted area

\begin{tabular}{|c|c|c|c|c|}
\hline \multirow[t]{2}{*}{ Acid } & \multicolumn{2}{|l|}{ Unpolluted } & \multicolumn{2}{|l|}{ Polluted } \\
\hline & $\begin{array}{l}\text { root vs. needle } \\
\text { on the bottom }\end{array}$ & $\begin{array}{l}\text { root vs. } \\
\text { needle on } \\
\text { the top }\end{array}$ & $\begin{array}{l}\text { root vs. needle } \\
\text { on the bottom }\end{array}$ & $\begin{array}{l}\text { root vs. } \\
\text { needle on } \\
\text { the top }\end{array}$ \\
\hline Acetic & $*$ & $* * *$ & n.s & $* * *$ \\
\hline Citric & $*$ & $* * *$ & $* *$ & n.s \\
\hline Fumaric & $* * *$ & $* * *$ & $*$ & $*$ \\
\hline Malic & $* * *$ & $* * *$ & $*$ & $* *$ \\
\hline Malonic & nd & nd & nd & nd \\
\hline Oxalic & $* * *$ & $* * *$ & $* * *$ & $* *$ \\
\hline Succinic & $* * *$ & $* * *$ & $*$ & $* *$ \\
\hline Sum & $* * *$ & $* * *$ & $* * *$ & n.s \\
\hline
\end{tabular}

n.s. not significant, n.d. not detected

$* * *<0.001, * *<0.01, *<0.05$
Besides, the content of ALMWOAs in roots was compared with their content in needles (both on the bottom and the top, separately) for plants collected from the unpolluted and polluted area. As it is shown in Table 2, significant differences were especially found for plants growing at the unpolluted area for almost all detectable ALMWOAs, but at different levels of significance.

However, no significant differences were found only for acetic acid determined in the root and the needle on the bottom and also citric acid and the sum of ALMWOAs in the root and the needle on the top, for plants collected from the polluted area.

\section{Phenolic compounds content in roots and needles of $P$. sylvestris $L$.}

The composition of roots did not contain all the compounds detected in the needles (Table 3). Among phenolic compounds nine acids (caffeic, chlorogenic, ferulic, gallic, $p$-coumaric, sinapic, syringic, $t$-cinnamic and vanilic) and eight flavonoids (apigenin, katechin, kaempferol, luteolin, naringenin, quercetin, rutin, vitexin) were detected in roots.

The dominant was $p$-coumaric acid. Gallic and vanilic acids were also abundant. The content of the acids ranged from 10.5 to $79.9 \mu \mathrm{g} \mathrm{g}^{-1} \mathrm{DW}$. The content of phenolic compounds found in the contaminated area was higher; the
Table 3 Contents $\left[\mu \mathrm{g} \mathrm{g}^{-1} \mathrm{DW}\right]$ of phenolic compounds in Pinus sylvestris $\mathrm{L}$. roots, needles from the bottom and the top growing at two experimental areas

\begin{tabular}{|c|c|c|c|c|c|c|}
\hline \multirow[t]{2}{*}{ Phenolic compound } & \multicolumn{2}{|l|}{ Root } & \multicolumn{2}{|c|}{ Needle on the bottom } & \multicolumn{2}{|c|}{ Needle on the top } \\
\hline & Unpolluted & Polluted & Unpolluted & Polluted & Unpolluted & Polluted \\
\hline 4-HBA & nd & nd & $1.77 \pm 0.14$ & $2.52 \pm 0.34^{*}$ & nd & $2.64 \pm 0.24 *$ \\
\hline Apigenin & $0.17 \pm 0.01$ & $0.27 \pm 0.02 *$ & $1.10 \pm 0.09$ & $1.59 \pm 0.23^{*}$ & $1.44 \pm 0.11$ & $1.65 \pm 0.08$ \\
\hline Caffeic a & $1.95 \pm 0.09$ & $4.19 \pm 0.18 *$ & $1.55 \pm 0.15$ & $2.27 \pm 0.28^{*}$ & $1.35 \pm 0.13$ & $3.35 \pm 0.12 *$ \\
\hline Chlorogenic a & $1.50 \pm 0.08$ & $2.21 \pm 0.18^{*}$ & $19.6 \pm 0.42$ & $21.5 \pm 1.27$ & nd & $1.65 \pm 0.10^{*}$ \\
\hline Ferulic a & $0.27 \pm 0.04$ & $0.78 \pm 0.03 *$ & $1.07 \pm 14$ & $1.51 \pm 0.15^{*}$ & $18.4 \pm 0.17$ & $6.27 \pm 1.23 *$ \\
\hline Gallic a & $48.7 \pm 1.19$ & $50.6 \pm 1.70$ & $2.21 \pm 0.13$ & $2.57 \pm 0.21$ & $4.13 \pm 0.14^{*}$ & $7.30 \pm 0.80$ \\
\hline Katechin & $1.37 \pm 0.22$ & $2.64 \pm 0.29 *$ & $5.60 \pm 0.12$ & $5.90 \pm 0.63$ & $6.53 \pm 0.66$ & $9.64 \pm 0.48 *$ \\
\hline Kaempferol & $0.18 \pm 0.02$ & $0.25 \pm 0.02 *$ & $0.44 \pm 0.02$ & $0.56 \pm 0.11$ & $1.04 \pm 0.45$ & $2.64 \pm 0.18^{*}$ \\
\hline Luteolin & $1.07 \pm 0.10$ & $0.96 \pm 0.04$ & $16.4 \pm 0.47$ & $26.4 \pm 1.33 *$ & $4.74 \pm 0.58$ & $19.2 \pm 1.69 *$ \\
\hline Naringenin & $2.02 \pm 0.17$ & $2.25 \pm 0.10$ & $0.19 \pm 0.01$ & $0.48 \pm 0.03 *$ & $0.25 \pm 0.03$ & $3.28 \pm 0.29 *$ \\
\hline$p$-Cumaric a & $71.3 \pm 1.24$ & $79.9 \pm 1.52^{*}$ & $4.62 \pm 0.27$ & $5.47 \pm 0.30^{*}$ & $2.06 \pm 0.09$ & $4.08 \pm 1.14^{*}$ \\
\hline Protocatechuic a & nd & nd & $38.0 \pm 0.57$ & $41.3 \pm 1.15^{*}$ & $10.4 \pm 0.54$ & $43.4 \pm 2.19 *$ \\
\hline Quercetin & $0.53 \pm 0.05$ & $0.94 \pm 0.09 *$ & $12.7 \pm 0.65$ & $15.3 \pm 0.91^{*}$ & $5.07 \pm 0.17$ & $12.6 \pm 0.62 *$ \\
\hline Rutin & $1.64 \pm 0.28$ & $3.69 \pm 0.14 *$ & $11.7 \pm 0.53$ & $13.3 \pm 1.12$ & $7.78 \pm 0.38$ & $10.4 \pm 1.23 *$ \\
\hline Salicylic a & nd & nd & $9.52 \pm 0.45$ & $12.1 \pm 0.84^{*}$ & $4.35 \pm 0.34$ & $12.5 \pm 1.22 *$ \\
\hline Sinapic a & $7.38 \pm 0.37$ & $8.94 \pm 0.43^{*}$ & $18.8 \pm 0.43$ & $22.4 \pm 1.42 *$ & $7.25 \pm 0.43$ & $20.5 \pm 1.29 *$ \\
\hline Syringic a & $0.12 \pm 0.03$ & $0.15 \pm 0.01$ & $28.2 \pm 0.69$ & $31.5 \pm 1.18^{*}$ & $11.7 \pm 1.23$ & $19.4 \pm 1.26^{*}$ \\
\hline t-Cinnamic a & $1.43 \pm 0.11$ & $1.32 \pm 0.11$ & $7.44 \pm 0.45$ & $8.98 \pm 0.39 *$ & $3.02 \pm 0.06$ & $11.2 \pm 0.45^{*}$ \\
\hline Vanilic a & $10.5 \pm 1.11$ & $12.0 \pm 0.87$ & $18.0 \pm 0.41$ & $18.6 \pm 1.22$ & $20.4 \pm 1.56$ & $30.8 \pm 0.93 *$ \\
\hline Vitexin & $2.89 \pm 0.11$ & $3.73 \pm 0.22 *$ & $4.37 \pm 0.28$ & $4.56 \pm 0.39$ & $3.25 \pm 0.09$ & $7.03 \pm 0.14 *$ \\
\hline
\end{tabular}

$n d$ not detected, $n s$ not significant

$* P \leq 0.05$ 
increases were significant for caffeic, chlorogenic, ferulic, $p$-coumaric and sinapic acids and apigenin, katechin, kaempferol, quercetin, rutin and vitexin. The profile of needles at the bottom included phenolic compounds from roots enriched by 4-HBA, protocatechuic and salicylic acids. The content of phenolic compounds exceeded $1 \mu \mathrm{g} \mathrm{g}^{-1}$ DW for nearly all components (besides kaempferol and naringenin) up to $\sim 31 \mu \mathrm{g} \mathrm{g}^{-1} \mathrm{DW}$. Among phenolic compounds protocatechuic acid $>$ siringic acids $>$ chlorogenic acid $>$ sinapic $>$ luteonin $>$ quercetin $>$ rutin were dominant and exceeded $10 \mu \mathrm{g} \mathrm{g}^{-1} \mathrm{DW}$. However, a significant increase in the content of phenolic compounds in the flotation tailings area was noted for 4-HBA, caffeic, ferulic, $p$-coumaric, protocatechiuc, salicylic (only in contaminated area), sinapic, syringic and $t$-cinnamic acids as well as apigenin, luteolin, naringenin and quercetin. The phenolic composition of top needles was similar to those at the bottom with the exception of 4-HBA and chlorogenic acid, which did not occur in the unpolluted area. The content of all the detected compounds was above $1 \mu \mathrm{g} \mathrm{g}^{-1} \mathrm{DW}$, but did not exceed $45 \mu \mathrm{g} \mathrm{g}^{-1} \mathrm{DW}$. A significantly higher content of phenolic compounds was detected in the flotation tailings, excluding apigenin. A reduction of the content of ferulic and galic acids was noted in the polluted area.

The PCA analyses were also performed for phenolic compounds to show similarities and differences in their content in the studied trees of $P$. sylvestris, where $83.95 \%$ $(66.59+17.36)$ of variability was explained. Dominant phenolic compounds in roots of $P$. silvestris from polluted and unpolluted areas were $p$-coumaric acid and kaempferol, while in case of needles on the bottom from both areas acids: protocatechuic, chlorogenic, synapic and also luteolin, quercetin and rutin (Fig. 2). Additionally, needles from the polluted area showed higher content of the majority of phenolic compounds than those from the unpolluted area.

Significant differences between the content of majority phenolic compounds determined in roots and needles (on the bottom and the top, separately) of plants collected from the unpolluted and polluted area were observed. According to data in Table 4, significant differences were found in almost all cases besides for sinapic acid in the roots and the needles on the top of plants from the unpolluted and p-cumaric acid for root vs. needle on the bottom from polluted area.
Fig. 2 Principal component analysis for phenolic compounds contents in Pinus sylvestris L. roots and needles ( $U$ Unpolluted, $P$ Polluted). Phenolic compounds: $1-4-$ HBA; 2-Apigenin; 3-Caffeic a.; 4-Chlorogenic a.; 5-Ferulic a.; 6-Gallic a.; 7-Katechin; 8-Kempferol; 9-Luteolin; 10-Naringenin; 11-p-Cumaric a.; 12-Protocatechuic a.; 13-Quercetinm; 14-Rutin; 15-Salicylic a.; 16-Sinapic a.; 17-Syringic a.; 18-t-Cinnamic a.; 19Vanilic a.; 20-Vitexin

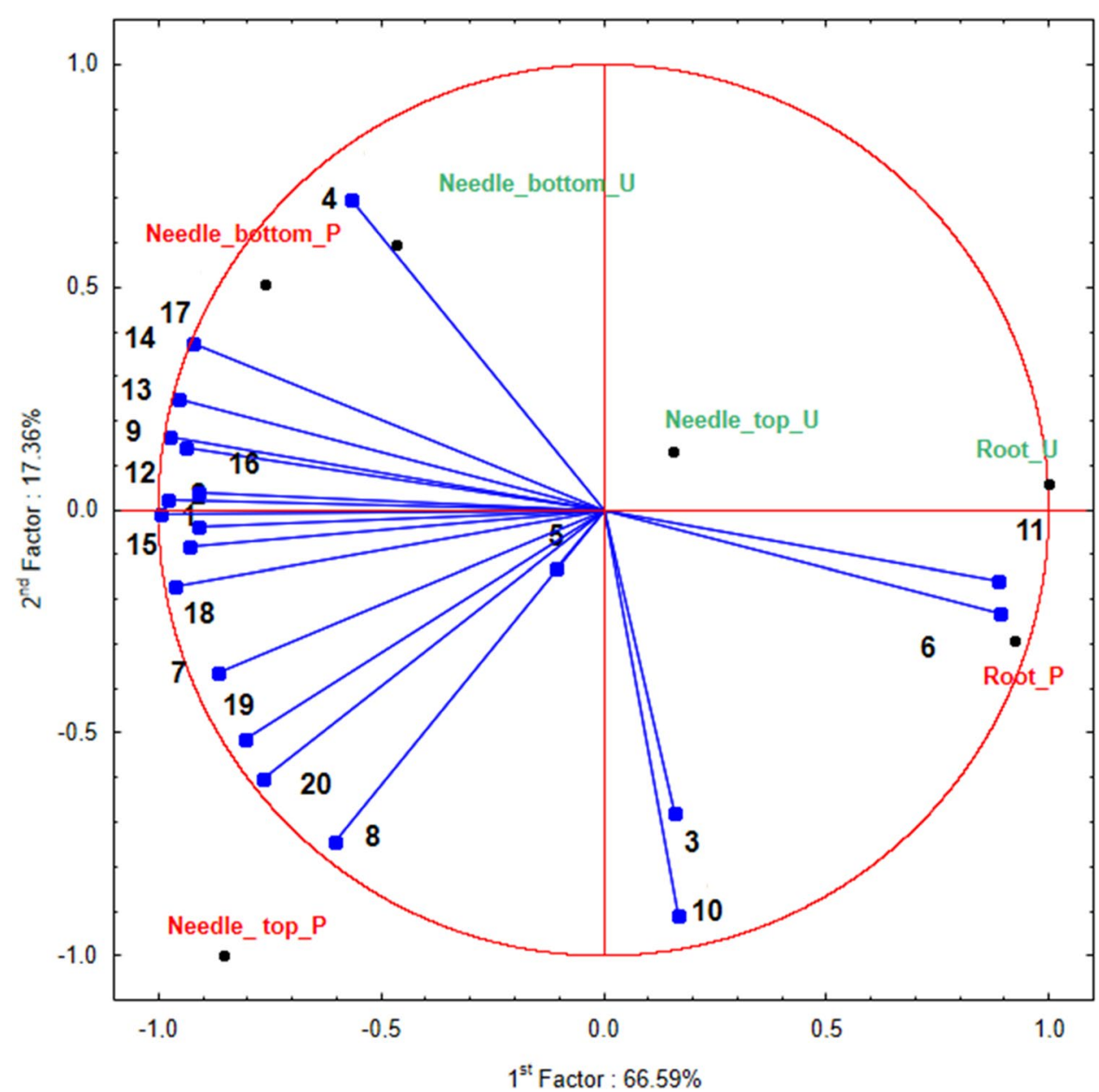


Table 4 Characteristics of differences between content of phenolic compounds in roots and needles separately for plants collected from unpolluted and polluted area

\begin{tabular}{|c|c|c|c|c|}
\hline \multirow[t]{2}{*}{ Acid } & \multicolumn{2}{|l|}{ Unpolluted } & \multicolumn{2}{|l|}{ Polluted } \\
\hline & $\begin{array}{l}\text { Root vs. needle on } \\
\text { the bottom }\end{array}$ & $\begin{array}{l}\text { Root vs. needle on } \\
\text { the top }\end{array}$ & $\begin{array}{l}\text { Root vs. needle on } \\
\text { the bottom }\end{array}$ & $\begin{array}{l}\text { Root vs. } \\
\text { needle on } \\
\text { the top }\end{array}$ \\
\hline 4-HBA & $* *$ & nd & $* *$ & $* *$ \\
\hline Apigenin & $* *$ & $* *$ & $* *$ & $* * *$ \\
\hline Caffeic a & $*$ & $* *$ & $* *$ & $* *$ \\
\hline Chlorogenic a & $* * *$ & $* * *$ & $* *$ & $*$ \\
\hline Ferulic a & $* *$ & $* *$ & $*$ & $* * *$ \\
\hline Gallic a & $* * *$ & $* * *$ & $* * *$ & $* * *$ \\
\hline Katechin & $* * *$ & $* * *$ & $* *$ & $* * *$ \\
\hline Kaempferol & $* * *$ & $*$ & $*$ & $*$ \\
\hline Luteolin & $* * *$ & $* *$ & $* * *$ & $* *$ \\
\hline Naringenin & $* *$ & $* *$ & $* * *$ & * \\
\hline$p$-Cumaric a & $* * *$ & $* * *$ & n.s & $* * *$ \\
\hline Protocatechuic a & $* * *$ & $* * *$ & $* * *$ & $* * *$ \\
\hline Quercetin & $* * *$ & $* * *$ & $* *$ & $* * *$ \\
\hline Rutin & $* * *$ & $* * *$ & $* *$ & $*$ \\
\hline Salicylic a & $* * *$ & $* *$ & $* *$ & $* *$ \\
\hline Sinapic a & $* * *$ & n.s & $* *$ & $* *$ \\
\hline Syringic a & $* * *$ & $* *$ & $* * *$ & $* *$ \\
\hline$t$-Cinnamic a & $* * *$ & $* * *$ & $* * *$ & $* * *$ \\
\hline Vanilic a & $* *$ & $* * *$ & $* *$ & $* * *$ \\
\hline Vitexin & $* *$ & * & $*$ & $* * *$ \\
\hline
\end{tabular}

n.s. not significant, $n . d$. not detected

$* * *<0.001, * *<0.01, *<0.05$

\section{Terpene contents in P. sylvestris L. needles}

In Table 5, the characteristics of terpenes emitted from the needles of pines growing in diverse forest area types are shown.

A total of 24 compounds were identified, present in pine needles collected from the polluted and unpolluted area. However, significant differences were found in terms of amounts of individual terpenes (Fig. 4).

In pine needles from the polluted area $\alpha$-pinene was the dominant compound. In needles collected from tree tops its mean content was $27.9 \%$, while in needles sampled from the middle sections of trees it was $23.3 \%$. In terms of the amounts emitted from these needles 3 -carene ranked second. In needles collected both from the tops and middle sections of trees growing in the contaminated area the levels of this compound were very similar, amounting to 16.3 and $16.7 \%$, respectively. Other monoterpenes were dominant in needles of pines growing in the unpolluted area. In needles from both the central and apical parts of trees 3-cerene was emitted in the greatest amounts, at 27.2 and $24.4 \%$, respectively. In turn, $\alpha$-pinene ranked second in terms of the emitted amounts among monoterpenes emitted from pine needles from the unpolluted area. The levels were $17.2 \%$ from needles in the apical parts and $16.7 \%$ from needles in the middle sections of trees. Differences between emissions of $\alpha$-pinene from needles of pines growing in the polluted and unpolluted areas amounted to approx. 10\% ( 27.9 vs. $17.2 \%$ and 16.9 vs. $23.3 \%$ ). There are significant differences between the content of dominant terpenes, as confirmed by statistical analysis (Table 5). Greater amounts of $\beta$-pinene were also emitted by needles of pines from the polluted area (2.93 and 3.31\%) in comparison to those from the unpolluted area (2.53 and 2.64\%). The emission of bornyl acetate from pine needles from the polluted area (tree top-1.45\% and middle sections-1.95\%) was almost threefold greater than the emission of this compound from pine needles from the unpolluted area (tree top- $0.59 \%$ and middle sections- $0.67 \%$ ).

Analyses of tricyclene and D-limonene contents showed that an approx. 1.5-fold greater amount of these compounds were recorded in needles from the polluted area in comparison to those from the unpolluted area. The amount of tricyclene in needles from the flotation tailings area was $2.10 \%$ (middle tree sections) and 2.01\% (tree tops), while in needles from unpolluted area it was $1.14 \%$ (middle tree sections) and $1.34 \%$ (tree tops). In turn, the amount of D-limonene in needles from the polluted area was $2.55 \%$ (tree tops) and 
Table 5 Contents $\left[\mu \mathrm{g} \mathrm{g}^{-1} \mathrm{DW}\right]$ of terpenes in Pinus sylvestris L. needles growing at two experimental areas

\begin{tabular}{|c|c|c|c|c|c|}
\hline \multirow[t]{2}{*}{ Compound } & \multirow[t]{2}{*}{ RI } & \multicolumn{2}{|c|}{ Needle on the bottom } & \multicolumn{2}{|c|}{ Needle on the top } \\
\hline & & Unpolluted & Polluted & Unpolluted & Polluted \\
\hline 2-Hexenal & 855 & $6.06 \pm 0.99$ & $2.58 \pm 0.89$ & $5.88 \pm 1.16$ & $2.61 \pm 1.04$ \\
\hline tricyclene & 926 & $1.14 \pm 0.75$ & $2.10 \pm 0.79$ & $1.34 \pm 0.70$ & $2.01 \pm 0.54$ \\
\hline$\alpha$-Pinene & 930 & $16.7 \pm 1.76^{*}$ & $23.3 \pm 1.99^{*}$ & $17.2 \pm 1.01^{*}$ & $27.9 \pm 7.67$ \\
\hline Camphene & 933 & $3.57 \pm 1.99$ & $5.97 \pm 1.82$ & $4.49 \pm 2.29$ & $5.30 \pm 1.30$ \\
\hline 4(10)Thujene & 937 & $0.42 \pm 0.35$ & $0.10 \pm 0.21$ & $0.69 \pm 0.14$ & nd \\
\hline$\beta$-Pinene & 980 & $2.53 \pm 1.59$ & $3.26 \pm 0.58$ & $2.64 \pm 0.96$ & $2.87 \pm 1.18$ \\
\hline$\alpha$-Myrcene & 990 & $7.26 \pm 1.20$ & $9.50 \pm 1.33$ & $7.57 \pm 1.09$ & $8.21 \pm 1.73$ \\
\hline 3-Carene & 1012 & $27.2 \pm 3.55^{*}$ & $16.7 \pm 1.72 *$ & $24.4 \pm 0.84^{*}$ & $16.3 \pm 2.80^{*}$ \\
\hline D-Limonene & 1030 & $1.58 \pm 0.19$ & $2.06 \pm 0.35$ & $1.64 \pm 0.11$ & $2.55 \pm 0.67$ \\
\hline$\alpha$-Ocimene & 1050 & $4.96 \pm 1.58$ & $4.26 \pm 3.84$ & $5.41 \pm 1.49$ & $5.87 \pm 3.40$ \\
\hline §-Terpinene & 1059 & $0.52 \pm 0.11$ & $0.14 \pm 0.27$ & $0.52 \pm 0.12$ & $0.33 \pm 0.24$ \\
\hline$(+)$-4-Carene & 1088 & $4.49 \pm 0.86$ & $3.44 \pm 0.34$ & $4.37 \pm 0.81$ & $4.20 \pm 0.16$ \\
\hline Bornyl acetate & 1288 & $0.67 \pm 0.90$ & $1.95 \pm 0.53$ & $0.59 \pm 0.69$ & $1.45 \pm 1.14$ \\
\hline Copaene & 1376 & $0.75 \pm 0.08$ & $0.65 \pm 0.46$ & $0.84 \pm 0.14$ & $0.32 \pm 0.37$ \\
\hline Caryophyllene & 1420 & $5.70 \pm 1.60$ & $5.01 \pm 0.50$ & $6.19 \pm 1.42$ & $5.83 \pm 1.42$ \\
\hline Alloaromaden-drene & 1448 & $0.34 \pm 0.40$ & $0.60 \pm 0.41$ & $0.34 \pm 0.41$ & $0.49 \pm 0.39$ \\
\hline Humulene & 1454 & $0.88 \pm 0.23$ & $0.78 \pm 0.10$ & $0.98 \pm 0.24$ & $0.69 \pm 0.53$ \\
\hline Unknown & 1466 & $0.92 \pm 0.75$ & $1.00 \pm 0.68$ & $0.87 \pm 0.58$ & $0.76 \pm 0.52$ \\
\hline Germacrene D & 1485 & $1.52 \pm 1.10$ & $3.47 \pm 1.16$ & $1.52 \pm 1.05$ & $2.92 \pm 2.19$ \\
\hline Eudesma-4(14)11-diene & 1488 & $1.01 \pm 0.76$ & $1.08 \pm 0.74$ & $1.31 \pm 1.14$ & $0.87 \pm 0.60$ \\
\hline §-Elemene & 1492 & $4.37 \pm 0.59$ & $4.38 \pm 0.72$ & $3.91 \pm 0.92$ & $3.71 \pm 1.04$ \\
\hline$\varsigma$-Cadinene & 1520 & nd & $0.90 \pm 1.80$ & nd & $\mathrm{Nd}$ \\
\hline$\varsigma$-Muurolene & 1526 & $2.87 \pm 0.35$ & $2.25 \pm 1.56$ & $2.93 \pm 0.47$ & $1.89 \pm 0.80$ \\
\hline Cadina-1(10).4-diene & 1534 & $3.82 \pm 0.54$ & $4.29 \pm 0.58$ & $3.79 \pm 0.55$ & $2.71 \pm 1.06$ \\
\hline Cubedol & 1536 & $0.65 \pm 0.24$ & $0.25 \pm 0.30$ & $0.59 \pm 0.24$ & $0.22 \pm 0.32$ \\
\hline
\end{tabular}

$n d$ not detected, $n s$ not significant $* P \leq 0.05$
$2.06 \%$ (middle sections), whereas in needles from the unpolluted area it was $1.64 \%$ (tree tops) and $1.58 \%$ (middle tree section). Among the other monoterpenes, greater amounts of camphene and $\alpha$-myrcene were recorded for needles from pines growing in the polluted area as compared to needles from the unpolluted area. Contents of $\alpha$-ocimene and (+) 4 -carene in needles collected both from middle and top sections in the polluted area and from the unpolluted locality were comparable (from 5.87 to $5.41 \%$ and from 4.26 to $4.96 \%)$. In needles from the polluted area the monoterpene $4(10)$-thujene was recorded in trace amounts $(0.10 \%)$; in needles from the unpolluted area it accounted for $0.69 \%$, in needles from the tree tops and $0.42 \%$ in needles from the middle sections of trees. Considerable differences were found in $\varsigma$-terpinene contents. Needles from tree tops from the area affected by the impact of flotation tailings area contained $0.33 \%$ of this compound, while in those from soil the level was nearly twofold greater $(0.52 \%)$. Analyses of needles collected from the middle parts of trees growing in the polluted area showed only $0.14 \% \varsigma$-terpinene, while in needles from unpolluted area the level was almost fourfold greater.

Sesquiterpene needles of pines growing in the flotation tailings area contained an over twofold greater content of germacrene D (middle tree sections $3.47 \%$ and tree tops $2.92 \%$ ) in comparison to pine needles from soil (middle tree sections $1.52 \%$ and tree tops $1.52 \%$ ). Slightly higher amounts of alloaromadendrene $(0.60 \%$ in middle tree sections and $0.49 \%$ in tree tops) were assayed in needles of pines from the polluted area as compared to needles from the unpolluted area ( $0.34 \%$ middle and top tree parts). In needles sampled from the apical parts of trees from flotation tailings the level of the sesquiterpene, copaene, was over 2.5-fold higher as compared to needles from the polluted area and a little higher in needles from the middle tree sections, at $0.75 \%$ and $0.65 \%$, respectively. Greater amounts of caryophyllene $(6.19 \%$ and $5.70 \%)$ and humulene $(0.98 \%$ and $0.88 \%$ ) were contained in needles of pines from soil in comparison to those from the polluted area $(5.83 \%$ vs. $5.70 \%$ and $0.69 \%$ vs. $0.88 \%$ ). Approximately twofold greater 

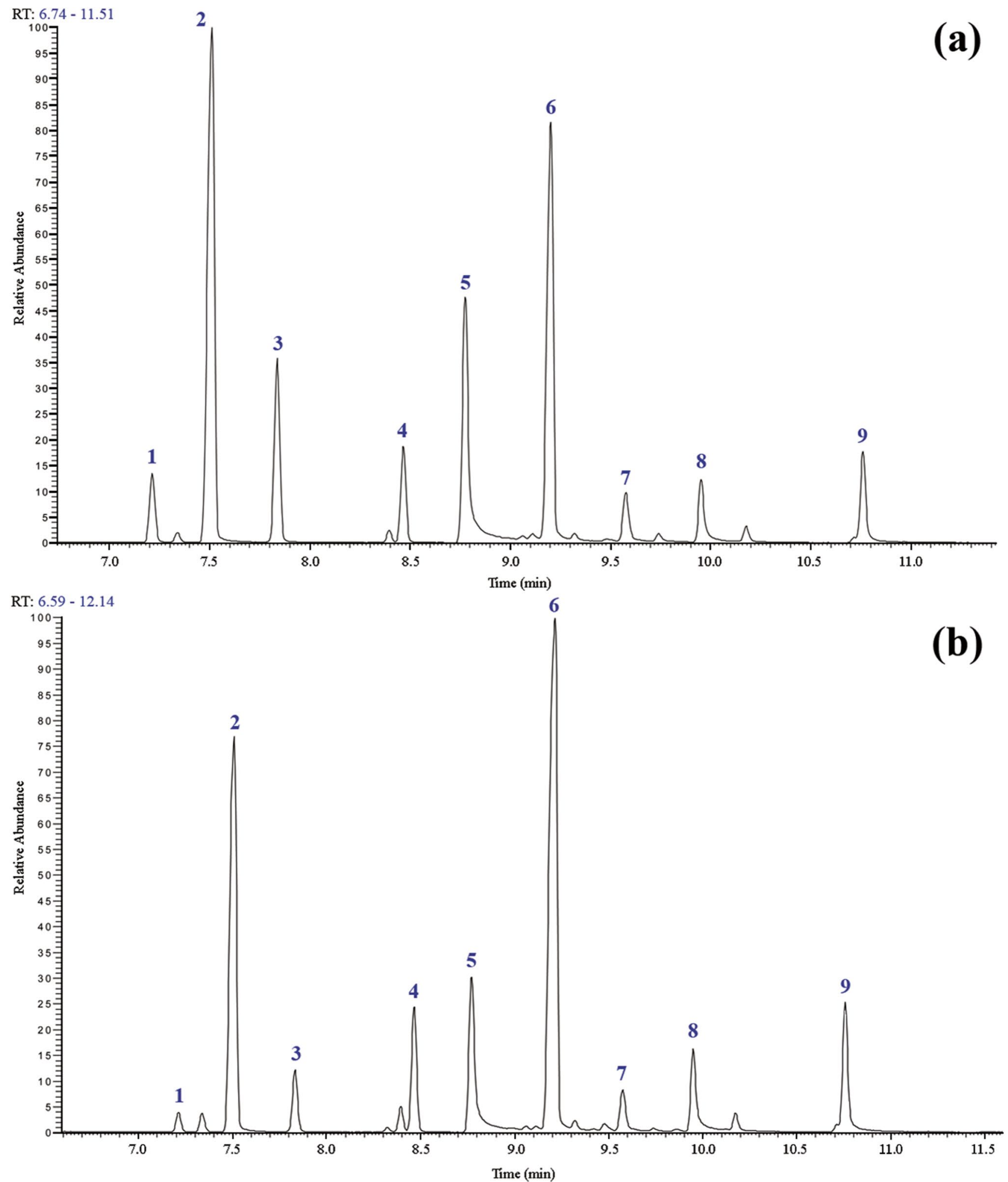

Fig. 3 Part of the chromatogram of volatile monoterpenes from Pinus sylvestris L. needles growing in a polluted (4a) and unpolluted (4b) area. Unpolluted area (4a): 1-2-Hexenal; $2-\alpha$-Pinene; 3 -Camphene; 4- $\beta$-Pinene; 5- $\alpha$-Myrcene; 6 -3-Carene;

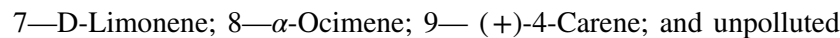
area (4b): $1-2$-Hexenal; $2-\alpha$-Pinene; 3 -Camphene; $4-\beta$-Pinene; 5- $\alpha$-Myrcene; 6-3-Carene; 7-D-Limonene; 8- $\alpha$-Ocimene; 9(+)-4-Carene 
levels of another sesquiterpene, cubedol, were assayed in needles from the unpolluted area (top tree parts $0.59 \%$ and middle tree sections $0.65 \%$ ) as compared to needles from the polluted area $(0.22 \%$ and $0.25 \%$, respectively). Other sesquiterpenes, such as eudesma-4(14)11-diene, $\varsigma$-elemene and $\varsigma$-muurolene, were found at comparable levels in needles of pines from both soil and from the flotation tailings area (Table 5).

In case of relationships between terpenes determined in $P$. sylvestris needles (on the bottom and the top) collected from studied areas, the PCA analysis $94.86 \%(66.75+28.11)$ of variability was explained, what showed a good reflect of observed relationships. From the unpolluted area, the higher content of 3-carene, 2-hexenal, 4(10)thujene, $\varsigma$-terpinene and cubedol than in needles from the polluted area was observed (Fig. 3). An opposite situation for $\beta$-pinene, boryl acetate, germacrene $\mathrm{D}$, camphene and tricyclene was recorded (Fig. 4).

\section{Discussion}

Different conditions of growing trees affect not only their growth and development but also the diversity of the amount and composition of biologically active compounds (ALMWOAs, phenolic compounds, terpenes, proteins, sugars) secreted to the rhizosphere, as well as created and accumulated in the roots or leaves or/and needles of trees (Viehweger 2014). In turn, the tree species is a decisive factor in the dendroremediation process and one that determines the essence of the plant's response to metals. Therefore, our research focused on the analysis of organic acids, phenolic compounds and terpenes as a response to the high content of metals in post-flotation wastes. Such studies are necessary, but what is most important for $P$. sylvestris is really new.

The rhizosphere is rich in constituents of plant root exudates (Badri and Vivanco 2009; Adeleke et al. 2017). Root exudates are composed of: ALMWOAs, sugars and proteins, as confirmed by their higher concentration in the root zone as compared to the main bulk of the soil (Jones 1998) and what should be emphasised is that their values can be highly
Fig. 4 Principal component analysis for terpenes in Pinus sylvestris L. needles ( $U$ Unpolluted, $P$ Polluted). Terpenes: 1-2-Hexenal; 2-Tricyclene; 3 - $\alpha$-Pinene; 4 -Camphene; 5-4(10)Thujene; 6- $\beta$-Pinene; $7-\alpha$-Myrcene; 8-3-Carene; 9-D-Limonene; $10-\alpha$-Ocimene;

11 - -Terpinene; 12 (+)-4-Carene; 13-Bornyl acetate; $14-$ Copaene; $15-$ Caryophyllene; 16-Alloaromaden-drene; 17-Humulene; 18-Unknown; 19-Germacrene D; 20_Eudesma4(14)11-diene; $21-\varsigma$-Elemene; 22- $\varsigma$-Cadinene;

23- $\varsigma$-Muurolene; 24 -Cadina1(10).4-diene; 25-Cubedol

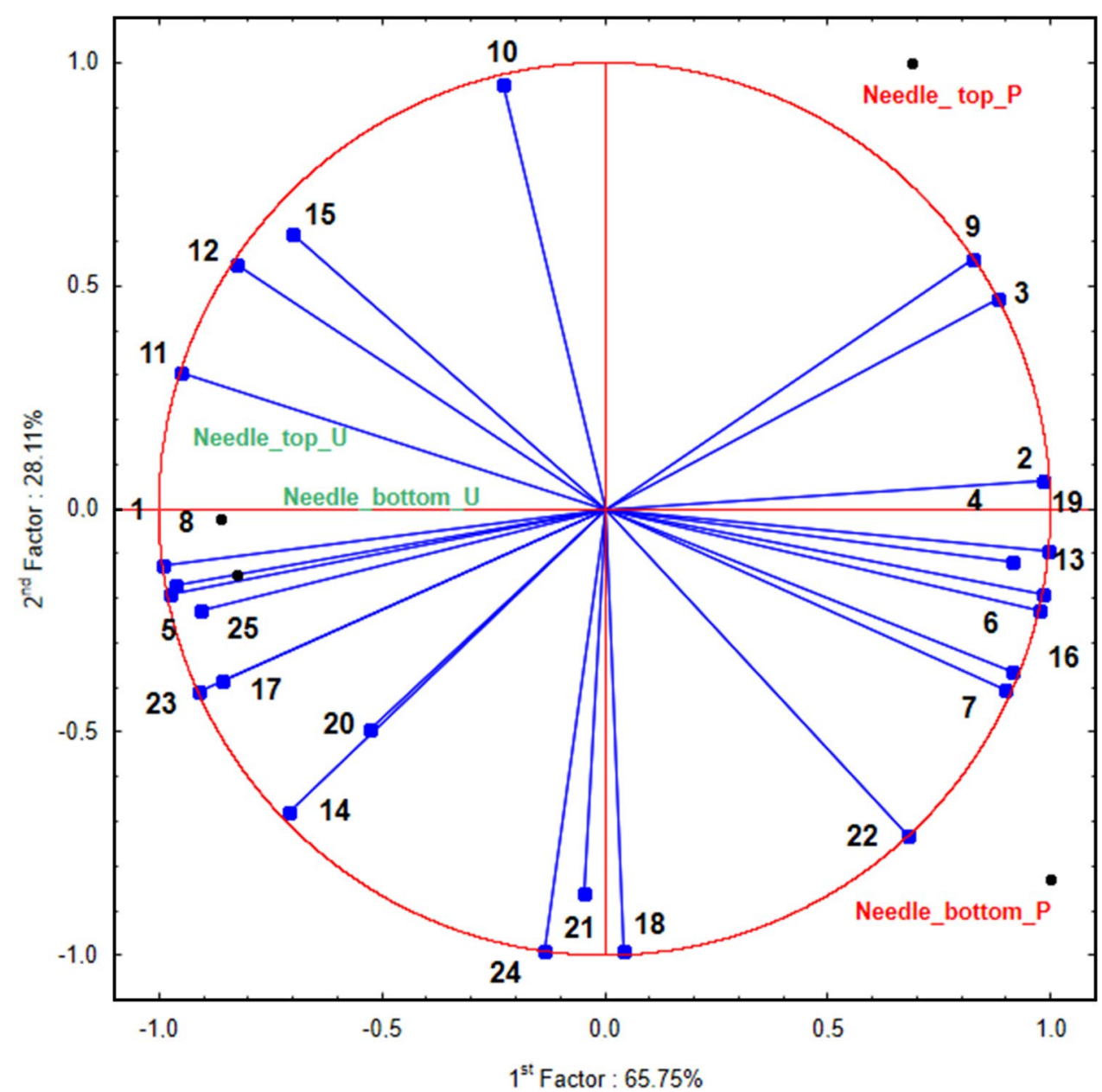


variable (Dakora and Philips 2002; Magdziak et al. 2017). This is related to/influenced by various signs of stress, such as physical changes in soil (temperature, light and/or soil moisture) (Adeleke et al. 2017), different types of soil (Ren et al. 2015; Dinh et al. 2017) and physiological changes (drought, nutrient deficiency or toxic metal pollution) (Jiang et al. 2017a, b; Dinh et al. 2017). From the above mentioned factors, both soil type and metal pollution are important in ALMWOAs exudation. Nevertheless, there is little information in the literature with respect to studies of organic acid creation and exudation induced by metal pollution in soil and comparison between ecologically different areas of $P$. sylvestris growth. Moreover, $P$. sylvestris is a plant that is able to adapt relatively easily to high levels of toxic metal pollution in flotation tailings and seems to be a promising woody plant for effective metal/metalloid uptake and translocation (Mleczek et al. 2018).

The presented work showed that $P$. sylvestris responded differently, a fact which was strictly dependent on the physicochemical parameters of the soil where $P$. sylvestris grew. Metal/metaloid (As, $\mathrm{Hg}$ or $\mathrm{Tl}$ ) present in flotation tailings were the main metals influencing the exudation of ALMWOAs by $P$. sylvestris roots; metal stress having been frequently reported to influence the exudation of ALMWOAs (Qin et al. 2007; Mucha et al. 2010; Meier et al. 2012). These elements have been previously shown to affect the exudation of oxalic, malonic and formic acids and were found as dominant in Ulmus leavis Pall. (Magdziak et al. 2019) and oxalic, malic and succinic acids in Pteris vittata ( $P$. vittata) (Das et al. 2017). Acids exudation has been frequently considered to be a resistance and detoxifying mechanism against metal contamination. This stimulation might therefore have been triggered to reduce metal toxicity by, for instance, complexing their ions. However, in the case of P. sylvestris, the significantly higher concentration of metals in flotation tailings inhibited the exudation of oxalic and malic acids, but highly induced citric acid secretion. The total concentrations of the analyzed acids were lower in comparison to the rhizosphere from the controlled area. In the case of oxalic acid a possible explanation of its decrease in concentration is exudation accompanied by plant uptake of the remaining ALMWOAs present in solution (Rocha et al. 2016), and in the case of malic acid being released, $P$. sylvestris roots will have taken up the metal-malic complexes formed during their growth. Nevertheless, an increased amount of citric acid in the rhizosphere could plays a detoxifying role at the level of the root zone, as well as increasing its amount in the root at the cellular level. Such a situation is highly probable according to literature data, but also in accordance with the results obtained from the analysis of acids in the roots. Metal-ALMWOAs complexes have been found in soil plant tissue (Walker and Welch 1987; Rellán-Álvarez et al. 2010; Rocha et al. 2016) and ALMWOAs are well-known for their ability to form complexes with metal ions, being involved in several processes such as metal tolerance, metal transport through xylem and metal sequestration in vacuoles (Clemens 2001). Therefore, in the presented study, ALMWOAs were determined not only in the root zone, but also in roots, thereby supporting the possible explanations for the content of the studied acids.

Woody plants can tolerate high metal pollution, utilising different defence mechanisms (Mleczek et al. 2018). The phenomenon of rhizodesposition has been shown to be a plant defence mechanism against metal toxicity (Miyasaka et al. 1991; Ryan et al. 2001; Pinto et al. 2008) and ALMOWAs obtained in roots could be the main molecules for decreasing metal toxicity in P. sylvestris roots (Magdziak et al. 2019). Moreover, the higher content of ALMWOAs obtained in pine roots may indicate possibilities of compartmentation of metals by the studied ALMWOAs in roots and their probable role as ligands, confirming previous research (Magdziak et al. 2017, 2019; Potdukhe et al. 2018). However, it should also be noted that concentration of ALMWOAs in the rhizosphere as well as in roots is strictly correlated, hence it may be simultaneously assumed that their ability to tolerate metal is also correlated. What is also important in the dendroremediation process is that pines have been shown to uptake increasing metal content in their roots as exposure to metal concentration increases (Mleczek et al 2018), with more than two times the content of ALMWOAs in roots in comparison to the control.

These data have also been extended with respect to the content of acids in the pine needles. Regardless of the height from which the needles were removed (the bottom or the top part of the tree) the same profile of analyzed acids was found, although with a significant difference in the content. In the case of needles collected from the bottom, significantly higher concentrations of ALMWOAs were determined as compared to needles growing at the top of the studied $P$. sylvestris. In addition, the needles from the bottom part of the pines growing on the flotation tailings were characterised by a significantly increased content of citric, fumaric, malic, oxalic and succinic acids, while the needles from the top part showed a significant increase of citric acid only. In studies previously carried out and described by Mleczek et al. (2018) it was also found that needles from the bottom part accumulate significantly higher concentrations of metals present in the floatation tailings, and from the top part, significantly less. Therefore, the marked increase in the total acid content within the needles from the bottom part of $P$. sylvestris (more than 2.5 times), could be a specific pine response to stress and may be a potential mechanism of detoxification of accumulated metals (Ma et al. 1997; Meier et al. 2012). The obtained results could also confirm previous literature reports on woody plants where a significant increase in the content of metals in the above-ground parts 
of studied woody plants was correlated with an increased content of metals/metalloids in the substrate (Magdziak et al. 2017, 2019). The studied ALMWOAs could maintain a balance in metal homeostasis and keep the toxicity within physiological limits in whole plants. ALMWOAs could also be used as chelates to transport, sequestrate and protect the pine from the negative effects of their growth and development (Kutrowska and Szelag 2014), which may be indicated by significant differences in the number of marked acids in the roots and their amount in the needles.

Changes in the quantity and content of phenolics in different plant tissues are reported under metal stress because they play an important role in defense and adaptive mechanisms (Martinez et al. 2016; Pradas del Real et al. 2017; Ullah et al. 2018; Drzewiecka et al. 2018). The study on P. sylvestris shows the quantitative and qualitative changes in roots and needles. Moreover significant differences in nerealy all phenolic matabolites content were detected between needles and roots in polluted and unpolluted area. The phenolic compounds detected in $P$. sylvestris roots occurred predominantly in small amounts not exceeding $10 \mu \mathrm{g} \mathrm{g}^{-1} \mathrm{DW}$. Only three components (gallic acid, $p$-coumaric acid and vanillic acid) archived a content $>10 \mu \mathrm{g} \mathrm{g}^{-1} \mathrm{DW}$. The dominant acids were $p$-coumaric and gallic acid. However, only the changes in $p$-coumaric acid in roots from different localizations were significant. Data concerning phenolic compounds in roots under metal stress are rare. Most authors have focused on total phenolic contents, pointing out the changes that occur under metal stress. A hydroponic experiment with $R$. communis confirmed the increase of phenolic compounds in roots and leaves under $\mathrm{Cd}$ and iron ( $\mathrm{Fe}$ - — stress; moreover, a correlation between phenolics and $\mathrm{Cd}$ was also confirmed (Ullah et al. 2018). Additionally, a lower content of phenolics in roots than in leaves has been recorded, although no profiling of the phenolics was conducted (Ullah et al. 2018). The induction of total phenolics in roots has also been noted in Phaseolus vulgaris under $\mathrm{Cu}$ treatements.

The significant increase of phenolic compounds in $P$. sylvestris from the contaminated area confirmed their contribution in defence mechanisms. Owing to their chemical structure, phenolic compounds are able to directly scavenge reactive oxygen species ROS, chelate ions of transition metals and suppress lipid peroxidation, making the diffusion of harmful radicals and peroxidative reactions difficult (Arora et al. 2000; Michalak 2006; Younis et al. 2018). ROS are generated via Fenton-Haber-Weiss reactions; however, some metals can induce the expression of enzymes such as lipoxygenases, which indirectly generate oxidation of polyunsaturated fatty acids (Kováčik et al. 2014). According to mechanisms proposed by Jiang et al. (2017a, b) for mangrove tissues and Cd-stress, the action of polyphenols may act in the apoplast and cytoplasm and include adsorption and lignification. Enhanced lignification is a natural barrier for metal ions which immobilise metals in the cell wall (Uraguchi et al. 2006). According to Jiang et al. (2017a, b), phenolic compounds are able to affect the bioactivity and translocation of toxic metals in plant tissues because the ability to chelate metals is associated with the presence of carboxyl and hydroxyl groups in the structure (Michalak 2006) and further translocation from cytoplasm to vacuole. Pradas del Real et al. (2017) pointed out that the increase in the contents of some phenolic compounds (quercetin-3-O-(2,6-di- $O$-rhamnosyl-galactoside and apiin) in the roots of Silene vulgaris under chrome $(\mathrm{Cr})$-stress was related to a defense mechanism based on free radical scavenging and chelation of $\mathrm{Cr}$. The confirmed changes in the content of phenolic compounds in P. sylvestris roots in the contaminated area suggested that acids are important compounds in defence mechanisms (caffeic, chlorogenic, ferulic, $p$-coumaric and sinapic) and some flavonoids (apigenin, katechin, kaempferol rutin, quercetin and vitaxin). In $P$. sylvestris roots under $\mathrm{Zn}$ stress phenolic changes caused the opposite reaction, related to enhanced lignification (Ivanov et al. 2012). The results of our study pointed to a significant increase of phenolic compounds, suggesting they have a prevailing role in the defence mechanism connected with antioxidant mechanisms rather than a structural role associated with lignification, although the precursors of lignin are present in roots (caffeic, $p$-coumaric, chlorogenic, ferulic and sinapic acids). A very surprising fact is that gallic acid is one of the most dominant compounds in roots, but changes in its content are not significant, even though gallic acid is known to be a strong antioxidant with the ability to directly scavenge ROS.

The study of López-Orenes et al. (2018) on Pinus halepensis (P. halepensis) growing on mine tailings suggests that phenolics could participate in the defense mechanism as chelating ligands playing a role in the detoxification and accumulation of metals and metalloids.

The phenolic composition of needles depends on their position in the crown, contrary to observations of Norway spruce (Kopačková et al. 2015). This could be a result of the age of the needle as demonstrated by (Kopačková et al. 2015). Little is known about the phenolic composition of needles. Roitto et al. (2005) found flavonoids in needles of $P$. sylvestris and the content alternated in their responses to metal content $(\mathrm{Ni}$ and $\mathrm{Cu}$ ) in soil. The results of our study confirmed a wide range of phenolic acids and flavonoids in needles on the bottom and the top with significant changes in the content of most of these components, especially in the top needles. The significant enhancement of phenolic acids and flavonoids pointed to their significant role in defense mechanisms, most likely associated with their ability to scavenge ROS (e.g. gallic acid, caffeic acid, $p$-coumaric acid (Benbettaieb et al. 2018) and functioning as ligands, protocatechiuc acid (Kováčik et al. 2010). In needles salicylic 
acid is present and the increase in its content in the contaminated area was observed as a result of its function in response mechanisms to environmental stressors, including metal stress (Arasimowicz-Jelonek et al. 2014; Drzewiecka et al. 2018). The reduction in ferulic and galic acids was probably connected with lignification, as also confirmed by (Ivanov et al. 2012).

Differing growth conditions for trees affect not only their growth and development but also result in varied amounts and composition of essential oils in needles and other plant parts. Both nutrients and pollutants found in the substrate influence the quantities and quality of the byproducts produced by plants (essential oils, tannins, resins, waxes) (Sembratowicz et al. 2008; Kupcinskiene et al. 2008; Sandre et al. 2014). Werner et al. (2004) recorded terpenoid contents in the roots of $P$. sylvestris seedlings growing in a substrate contaminated with heavy metals and stated that in the case of polluted substrate roots showed significantly lower terpenoid levels. Kupcinskiene et al. (2008) reported that the most heavily polluted environments trigger an increase in the concentrations of sabinene and $\beta$-pinene in needles of pines growing in the vicinity of industrial facilities. Along transects an increase was observed in the amount of some diterpenes and a decrease in the components of the shorter chain essential oils. In this study, lower amounts of certain diterpenes were recorded, i.e. $\varsigma$-muurolene, cadina$1(10), 4$-diene and cubedol in needles of pines growing in the heavily contaminated environment. Judzentiene et al. (2006) reported the dominance of two basic monoterpenes ( $\alpha$-pinene and 3-carene) in oils from needles of pines growing in an environment with elevated ammonia levels in the air. However, it was stated in that study that the contents of a terpene, 3-carene (22.7-33.7\%), exceeded those of $\alpha$-pinene (19.8-35.0\%). In contrast, needles from the polluted area showed an opposite relationship as the amounts of $\alpha$-pinene (23.23-26.57\%) exceeded those of 3-carene (16.57-16.89\%). Similarly, to the authors of this study, Dziri and Hosni (2012) also observed an increase in the contents of $\beta$-pinene (29.5\% and $22.0 \%$ ) in needles of $P$. halepensis from a polluted area in comparison to control samples (11.6\%). Supuka et al. (1997) recorded lesser amounts of terpenes in essential oils from needles collected in the area of Nitra than in oils from needles sampled in the arboretum. Moreover, like the findings of this study, analyses of the material collected in Nitra revealed an increase in $\beta$-pinene contents in needles from an urban area in comparison to needles collected from an unpolluted area. Urban conditions caused a changed proportion of $\alpha$-pinene in relation to the following terpenes: $\alpha$-phelandrene, 1.8 -cineole, terpineol, citral and carvone (Supuka and Berta 1998). These changes discovered in the contents of terpenes in needles of Pinus strobus L. have shown that the group of secondary metabolites is an important biochemical marker of the environmental impact on woody plants. An increase in $\alpha$-pinene contents in pine needles from an area polluted by dusts emitted by a cement plant was reported by Hosni et al. (2014). In the control samples those authors recorded $48.1 \%$ of this compound, while in samples from the polluted area it was $62.2 \%$ and $63.8 \%$, respectively.

All the cited literature data are concerned with chemical changes in essential oils of plants growing in contaminated environments. Thus, the results of the performed experiment are consistent with the data published by other authors. According to Oviasogie et al. (2009) production of essential oil is an indicator of plant adaptation to habitat conditions and helps plants to easily adjust to environmental stress conditions, among others: drought, intense radiation, high temperature, high heavy metal contents. Natural selection favours the survival of plants with a higher concentration of essential oils which enhance their adaptive value (Stevovič et al. 2011). This plant defense mechanism caused an increase in the content of essential oils in the examined needles of $P$. sylvestris L. growing in a polluted area. However, the role of selected monoterpenes, especially $\alpha$-pinene, in this mechanism requires further research.

Another interesting aspect related to monoterpens is their role in biotic interactions and soil processes. Ludley et al. (2009) analyzed the monoterpene content and distribution in the litters and roots of three species of conifer: Picea abies, Picea sitchensis and Pinus sylvestris. They showed an environmentally relevant content of $\alpha$ - or $\beta$-pinene sufficient to increase mycorrhizal colonization of Picea abies root tips and to decrease the respiration rate of two species of saprotrophic fungi, in relatively natural substrata. Smolander et al. (2006) investigated the impact of monoterpens on soil microbes. According to authors there were differences in the response of both microbial biomass $\mathrm{C}$ and $\mathrm{N}$ to different monoterpenes, $\alpha$ - and $\beta$-pinene being the most inhibitory whereas myrcene inhibited only microbial biomass $\mathrm{N}$ in the presence of arginine. Generally, they stated that monoterpens have negative effects on soil $\mathrm{N}$ transformations but may serve as a carbon and energy source for some soil microbes.

\section{Conclusion}

The obtained results reveal how the growth environment has a significant influence on the content of organic compounds in the rhizosphere, roots and needles. In the case of the concentration of ALMWOAs secreted into soil and into highly toxic flotation tailings, the root zone was similar. However, in roots and needles their value was significantly higher in tissue from the polluted area. Such an observation indicates that ALMWOAs may be one of the most important factors in P. sylvestris species, contributing to metal/ metalloid detoxification, involved in several processes such 
as metal tolerance, metal transport through xylem and metal sequestration in vacuoles. Moreover, the changes in the phenolic profile of roots and needles point to a major role in the defence mechanism associated with antioxidant mechanisms based on the scavenging ROS, functioning as ligands rather than having a structural role connected with lignification, although the precursors of lignin are present in roots (caffeic, $p$-coumaric, chlorogenic, ferulic and sinapic acids. The analysis of the results of volatile terpenes in pine needles growing in substrate contaminated with sludge and uncontaminated soil indicates a different dominance of the main monoterpenes. The contaminated soil had a significant effect on the reduction of 3 -carene and the increase of $\alpha$-pinene in pine needles.

Author contribution statement $\mathrm{PG}, \mathrm{MM}$ and $\mathrm{AM}$ chose experimental areas and designed the study; WJC, BM, TK, $\mathrm{PN}$ and MM selected appropriate research material for testing; ZM, MG, BW, MZ analysed samples and took part in writing the manuscript, MG, AMP performed the statistical analysis; PN methodology. All authors contributed to writing the final version of the manuscript.

Acknowledgements This publication was financially supported by the framework of Ministry of Science and Higher Education programme "Regional Initiative of Excellence" in years 2019-2022, Project No. 005/RID/2018/19 and Grant Code Opus 2014/15/B/NZ9/02172 for Piotr Goliński, from the National Science Centre of Poland. The authors would also like to thank the staff of the Durowo Forest Division, especially the forest inspector Sławomir Kołacz and forest ranger Robert Wieczorek.

\section{Compliance with ethical standards}

Conflict of interest The authors declare that there is no conflict of interest regarding the publication of this paper.

Open Access This article is licensed under a Creative Commons Attribution 4.0 International License, which permits use, sharing, adaptation, distribution and reproduction in any medium or format, as long as you give appropriate credit to the original author(s) and the source, provide a link to the Creative Commons licence, and indicate if changes were made. The images or other third party material in this article are included in the article's Creative Commons licence, unless indicated otherwise in a credit line to the material. If material is not included in the article's Creative Commons licence and your intended use is not permitted by statutory regulation or exceeds the permitted use, you will need to obtain permission directly from the copyright holder. To view a copy of this licence, visit http://creativecommons.org/licenses/by/4.0/.

\section{References}

Adams RP (2007) Identification of essential oil components by gas chromatography/mass spectrometry, 4th edn. Allured Publ. Corp, Carol Stream
Adeleke R, Nwangburuk C, Oboirien B (2017) Origins, roles and fate of organic acids in soils: a review. S Afr J Bot 108:393-406. https ://doi.org/10.1016/j.sajb.2016.09.002

Adeniji BA, Budimir-Hussey MT, Macfie SM (2010) Production of organic acids and adsorption of $\mathrm{Cd}$ on roots of durum wheat (Triticum turgidum L. var. Durum). Acta Physiol Plant 32:1063-1072. https://doi.org/10.1007/s11738-010-0498-6

Arasimowicz-Jelonek M, Floryszak-Wieczorek J, Drzewiecka K, Chmielowska-Bąk J, Abramowski D, Izbiańska K (2014) Aluminium induces cross-resistance of potato Phytophthora infestans. Planta 4:679-694. https://doi.org/10.1007/s00425-013-2008-8

Arora A, Byrem TM, Nair MG, Strasburg GM (2000) Modulation of liposomal membrane fluidity by flavonoids and isoflavonoids. Arch Biochem Biophys 373:102-109. https://doi.org/10.1006/ abbi.1999.1525

Azooz MM, Youssef MM, Al-Omair MA (2011) Comparative evaluation of zinc and lead and their synergistic effects on growth and some physiological responses of Hassawi okra (Hibiscus esculentus) seedlings. Am J Plant Physiol 6:269-282. https://scialert.net/ abstract/?doi=ajpp.2011.269.282

Badri DV, Vivanco JM (2009) Regulation and function of root exudates. Plant Cell Environ 32:666-681. https://doi.org/10.111 1/j.1365-3040.2009.01926.x

Bakkali F, Averbeck S, Averbeck D, Idaomar M (2008) Biological effects of EOs-a review. Food Chem Toxicol 46:446-475. https ://doi.org/10.1016/j.fct.2007.09.106

Benbettaieb N, Nyagaya J, Seuvre AM, Debeaufort F (2018) Antioxidant activity and release kinetics of caffeic and p-coumaric acids from hydrocolloid-based active films for healthy packaged food. J Agri Food Chem 66:6906-6916. https://doi.org/10.1021/ acs.jafc. 8 b01846

Blaylock MJ, James BR (1994) Redox transformations and plant uptake of selenium resulting from root-soil interactions. Plant Soil 158:112. https://doi.org/10.1007/BF00007911

Budzyńska S, Krzesłowska M, Niedzielski P, Goliński P, Mleczek M (2017) Arsenite phytoextraction and its influence on selected nutritional elements in one-year-old tree species. Microchem J 133:530-538. https://doi.org/10.1016/j.microc.2017.04.022

Budzyńska S, Mleczek M, Goliński P, Rutkowski P, Niedzielski P (2017) The influence of As forms in substrate on the phytoextraction of this metalloid in Ulmus laevis Pall organs - Pot experiment. Microchem J 132:333-340. https://doi.org/10.1016/j.microc.2017.01.030

Chojnacki B, Cichy W (1995) Zawartość monoterpenów igliwia sosny zwyczajnej (Pinus sylvestris L.) narażonej na działanie emisji przemysłowych. Sylwan 4:47-55

Clemens S (2001) Molecular mechanisms of plant metal tolerance and homeostasis. Planta 212:475-486. https://doi.org/10.1007/s0042 50000458

Dakora FD, Phillips DA (2002) Root exudates as mediators of mineral acquisition in low-nutrient environments. Plant Soil 245:35-47. https://doi.org/10.1023/A:1020809400075

Das S, Choua ML, Jeana JS, Yanga HJ, Kim PJ (2017) Arsenic-enrichment enhanced root exudates and altered rhizosphere microbial communities and activities in hyperaccumulator Pteris vittata. J Hazard Mater 325:279-287. https://doi.org/10.1016/j.jhazm at.2016.12.006

Dinh QT, Li Z, Tran TAT, Wang D, Liang D (2017) Role of organic acids on the bioavailability of selenium in soil: a review. Chemosphere 184:618-635. https://doi.org/10.1016/j.chemospher e.2017.06.034

Dob T, Berramdane T, Chelgoum Ch (2005) Chemical composition of essential oil of Pinus halepensis Miller growing in Algeria. CR Chim 8:1939-1945. https://doi.org/10.1016/j.crci.2005.05.007

Drzewiecka K, Mleczek M, Gąsecka M, Magdziak Z, Budka A, Chadzinikolau T, Kaczmarek Z, Goliński P (2017) Copper and nickel cotreatment alters metal uptake and stress parameters of 
Salix purpurea $\times$ viminalis. J Plant Physiol 216:125-134. https:// doi.org/10.1016/j.jplph.2017.04.020

Drzewiecka K, Gąsecka M, Rutkowski P, Magdziak Z, Goliński P, Mleczek M (2018) Arsenic forms and their combinations induce differences in phenolic accumulation in Ulmus laevis Pall. J Plant Physiol 220:34-42. https://doi.org/10.1016/j.jplph.2017.09.013

Dziri S, Hosni K (2012) Effects of cement dust on volatile oil constituents and antioxidative metabolism of Aleppo pine (Pinus halepensis) needles. Acta Physiol Plant 34:1669-1678. https:// doi.org/10.1007/s11738-012-0962-6

Fuksman IL (2002) Biochemical response of Pinus sylvestris L. to stress factors. Rast Resurs 38:126-133

Gąsecka M, Mleczek M, Jutrzenka A, Goliński P, Stuper-Szablewska K (2017) Phenolic compounds in leaves of Salix species and hybrids growing under different soil conditions. Chem Ecol 33:196-212. https://doi.org/10.1080/02757540.2017.1289186

Gilles M, Zhao J, An M, Agboola S (2010) Chemical composition and antimicrobial properties of EOs of three Australian Eucalyptus species. Food Chem 119:731-737. https://doi.org/10.1016/j.foodc hem.2009.07.021

Głowacki S (1994) Zawartość olejków eterycznych w igliwiu drzew leśnych. Sylwan 1:27-42

Gonçalves LA, Barbosa LCA, Azevedo AA, Casali VWD, Nascimento EA (2003) Produção e composição do óleo essencial de alfavaquinha (Ocimim selloi Benth.) em resposta a dois níveis de radiação solar. Rev Bras Plantas Med 6:8-14

Grochowski W (1990) Uboczna produkcja leśna. [Side forest production.] PWN Warszawa. [in Polish]

Hammer D, Keller C (2002) Changes in the rhizosphere of metal-accumulating plants evidenced by chemical extractants. J Environ Qual 31:1561-1569

Hosni K, Hassen I, M'Rabet Y, Casabianca H (2014) Biochemical response of Cupressus sempervirens to cement dust: Yields and chemical composition of its essential oil. Arab J Chem 12:13081314. https://doi.org/10.1016/j.arabjc.2014.10.042

Huang S, Jia X, Zhao Y, Chang Y, Bai (2016) Response of Robinia pseudoacacia $\mathrm{L}$. rhizosphere microenvironment to $\mathrm{Cd}$ and $\mathrm{Pb}$ contamination and elevated temperature. Appl Soil Ecol 108:269277. https://doi.org/10.1016/j.apsoil.2016.09.002

Ivanov YV, Savochkin YV, Kuznetsov VV (2012) Scots pine as a model plant for studying the mechanisms of conifers adaptation to heavy metal action: 2 . Functioning of antioxidant enzymes in pine seedlings under chronic zinc action. Russ J Plant Physiol 59:50. https://doi.org/10.1134/S1021443712010098

Jiang S, Weng B, Liu T, Su Y, Liu J, LuYan HC (2017) Response of phenolic metabolism to cadmium and phenanthrene and its influence on pollutant translocations in the mangrove plant Aegiceras corniculatum (L.) Blanco (Ac). Ecotoxicol Environ Saf 141:290 297. https://doi.org/10.1016/j.ecoenv.2017.03.041

Jiang S, Xie F, Lu H, Liu J, Yan C (2017) Response of low-molecular-weight organic acids in mangrove root exudates to exposure of polycyclic aromatic hydrocarbons. Environ Sci Pollut Res 24:12484-12493. https://doi.org/10.1007/s11356-017-8845-4

Jones DL (1998) Organic acids in the rhizosphere-a critical review. Plant Soil 205:25-44. https://doi.org/10.1023/A:100435600

Judzentiene A, Slizyte J, Stikliene A, Kupinskiene E (2006) Characteristics of essential oil composition in the needles of young Scots pine (Pinus sylvestris L.) stands growing along an aerial ammonia gradient. Chemija 17:67-73

Kainulainen P, Oksanen J, Palömaki V, Holopainen T (1992) Effect of drought and waterlogging stress on needle monoterpenes of Picea abies. Can J Bot 70:1613-1616. https://doi.org/10.1139/b92-203

Koo B, Chen W, Chang A, Page A, Granato T, Dowdy R (2010) A root exudates based approach to assess the long-term phytoavailability of metals in biosolids-amended soils. Environ Pollut 158:25822588. https://doi.org/10.1016/j.envpol.2010.05.018
Kopačková V, Lhotáková Z, Oulehle F, Albrechtová J (2015) Assessing forest health via linking the geochemical properties of a soil profile with the biochemical parameters of vegetation. Int J Environ Sci Technol 12:1987. https://doi.org/10.1007/s13762-014-0602-3

Kováčik J, Klejdus B, Hedbavny J, Bačkor M (2010) Effect of copper and salicylic acid on phenolic metabolites and free amino acids in Scenedesmus quadricauda (Chlorophyceae). Plant Sci 178:307-311. https://doi.org/10.1016/j.plantsci.2010.01.009

Kováčik J, Babula P, Klejdus B, Hedbavny J (2014) Comparison of oxidative stress in four Tillandsia species exposed to cadmium. Plant Physiol Biochem 80:33-40. https://doi.org/10.1016/j.plaph y.2014.03.015

Kupcinskiene E, Stikliene A, Judzentiene A (2008) The essential oil qualitative and quantitative composition in the needles of Pinus sylvestris L. growing along industrial transects. Environ Poll 155:481-491. https://doi.org/10.1016/j.envpol.2008.02.001

Kutrowska A, Szelag M (2014) Low-molecular weight organic acids and peptides involved in the long-distance transport of trace metals. Acta Physiol Plant 36:1957-1968. https://doi.org/10.1007/ s11738-014-1576-y

López-Orenes A, Bueso MC, Conesa H, ACalderón AA, Ferrera MA (2018) Seasonal ionomic and metabolic changes in Aleppo pines growing on mine tailings under Mediterranean semi-arid climate. Sci Total Environ 637-638:625-635. https://doi.org/10.1016/j. scitotenv.2018.05.049

Lord H, Pawliszyn J (2000) Evolution of solid-phase microextraction technology. J Chromatogr A 885:153-193. https://doi. org/10.1016/S0021-9673(00)00535-5

Ludley KE, Jickells SM, Chamberlain PM, Whitaker J, Robinson CH (2009) Distribution of monoterpenes between organic resources in upper soil horizons under monocultures of Picea abies, Picea sitchensisand Pinus sylvestris. Soil Biol Biochem 41:1050-1059. https://doi.org/10.1016/j.soilbio.2009.02.002

Ma JF, Zheng SJ, Matsumoto H (1997) Specific secretion of citric acid induced by Al stress in Cassia tora L. Plant Cell Physiol 38:10191025. https://doi.org/10.1093/oxfordjournals.pcp.a029266

Magdziak Z, Mleczek M, Rutkowski P, Goliński P (2017) Diversity of low-molecular weight organic acids synthesized by Salix growing in soils characterized by different $\mathrm{Cu}, \mathrm{Pb}$ and $\mathrm{Zn}$ concentrations. Acta Physiol Plant 39:137. https://doi.org/10.1007/s1173 8-017-2434-5

Magdziak Z, Goliński P, Gąsecka M, Budka A, Mleczek M (2019) Differentiation in low molecular weight organic acids exudation into rhizosphere and their creation in Ulmus laevis Pall organs treated by As-pot experiment. Chem Ecol 35:36-53. https://doi. org/10.1080/02757540.2018.1531986

Martinez V, Mestre TC, Rubio F, Girones-Vilaplana A, Moreno DA, Mittler R, Rivero RM (2016) Accumulation of flavonols over hydroxycinnamic acids favors oxidative damage protection under abiotic stress. Front Plant Sci 7:1-17. https://doi.org/10.3389/ fpls.2016.00838

Meier S, Alvear M, Borie F, Aguilera P, Ginocchio R, Cornejo P (2012) Influence of copper on root exudate patterns in some metallophytes and agricultural plants. Ecotoxicol Environ Saf 75:8-15. https://doi.org/10.1016/j.ecoenv.2011.08.029

Michalak A (2006) Phenolic compounds and their antioxidant activity in plants growing under heavy metal stress. Pol J Environ Stud 15:523-530

Miyasaka SC, Buta JG, Howel RK, Foy CD (1991) Mechanism of aluminium tolerance in snap beans. Root exudation of citric acid. Plant Physiol 96:737-743. https://doi.org/10.1104/pp.96.3.737

Mleczek M, Rutkowski P, Niedzielski P, Goliński P, Gąsecka M, Kozubik T, Dąbrowski J, Budzyńska S, Pakuła J (2016) The role of selected tree species in industrial sewage sludge/flotation tailing management. Int J Phytoremediat 8:1086-1095. https://doi. org/10.1080/15226514.2016.1183579 
Mleczek M, Gąsecka M, Waliszewska B, Magdziak Z, Szostek M, Rutkowski P, Kaniuczak J, Zborowska M, Budzyńska S, Mleczek M, Niedzielski P (2018) Salix viminalis L.—a highly effective plant in phytoextraction of elements. Chemosphere 212:67-78. https:// doi.org/10.1016/j.chemosphere.2018.08.055

Mleczek M, Goliński P, Waliszewska B, Mocek A, Gąsecka M, Zborowska M, Magdziak Z, Cichy WJ, Mazela B, Kozubik T, Mocek-Płóciennik A, Moliński W, Niedzielski P (2019) The importance of substrate compaction and chemical composition in the phytoextraction of elements by Pinus sylvestris L. J Environ Sci Heal A 53:1029-1038. https://doi.org/10.1080/10934529.2018.1471116

Mucha AP, Almeida CMR, Bordalo AA, Vasconcelos MTSD (2010) LMWOA (low molecular weight organic acid) exudation by salt marsh plants: natural variation and response to $\mathrm{Cu}$ contamination. Estuar Coast Shelf Sci 88:63-70. https://doi.org/10.1016/j.ecss.2010.03.008

Oviasogie PO, Omoruyi E, Okoro D, Ndiokwere CL (2009) Evaluation of physicochemical properties and distribution of $\mathrm{Pb}, \mathrm{Cd}, \mathrm{Cr}$ and $\mathrm{Ni}$ in soils and growing plants around refuse dumpsites in Akure, Nigeria. Afr J Biotechnol 8:2757-2762

Pinto AP, Simões I, Mota AM (2008) Cadmium impact on root exudates of sorghum and maize plants: a speciation study. J Plant Nutr 31:1746-1755. https://doi.org/10.1080/01904160802324829

Placek A, Grobelak A, Kacprzak M (2016) Improving the phytoremediation of heavy metals contaminated soil by use of Sewage Sludge. Int J Phytoremediat 18:605-618. https://doi.org/10.1080/15226 514.2015.1086308

Potdukhe RM, Bedi P, Sarangi BK, Pandey RA, Thul ST (2018) Root transcripts associated with arsenic accumulation in hyperaccumulator Pteris vittata. J Biosci 43:105-115. https://doi.org/10.1007/ s12038-018-9735-8

Pradas del Real AE, Silvan JM, de Pascual-Teresa S, Guerrero A, García-Gonzalo A, Lobo MC, Pérez-Sanz A (2017) Role of the polycarboxylic compounds in the response of Silene vulgaris to chromium. Environ Sci Pollut Res 24:5746. https://doi. org/10.1007/s11356-016-8218-4

Qin R, Hirano Y, Brunner I (2007) Exudation of organic acid anions from poplar roots after exposure to $\mathrm{Al}, \mathrm{Cu}$ and $\mathrm{Zn}$. Tree Physiol 27:313-320. https://doi.org/10.1093/treephys/27.2.313

Rellán-Álvarez R, Giner-Martínez-Sierra J, Orduna J, Orera I, Rodríguez-Castrillón JÁ, Abadía G-A, Álvarez-Fernández JA (2010) Identification of a tri-Iron(III), tri-Citrate complex in the xylem sap of Iron-deficient tomato resupplied with iron: new insights into plant iron long-distance transport. Plant Cell Physiol 51:91102. https://doi.org/10.1093/pcp/pcp170

Ren ZL, Tella M, Bravin MN, Comans RNJ, Dai J, Garnier JM, Sivry Y, Doelsch E, Straathof A, Benedetti MF (2015) Effect of dissolved organic matter composition on metal speciation in soil solutions. Chem Geol 398:61-69. https://doi.org/10.1016/j.chemgeo.2015.01.020

Rocha ACS, Almeida CMR, Basto MCP, Vasconcelos MTSD (2016) Marsh plant response to metals: Exudation of aliphatic low molecular weight organic acids (ALMWOAs). Estuar Coast Shelf Sci 171:77-84. https://doi.org/10.1016/j.ecss.2016.01.027

Roitto M, Rautio P, Julkunen-Tiitto R, Kukkola E, Huttunen S (2005) Changes in the concentrations of phenolics and photosynthates in Scots pine (Pinus sylvestris L.) seedlings exposed to nickel and copper. Environ Pollut 137:603-609. https://doi.org/10.1016/j. envpol.2005.01.046

Ryan PR, Delhaize E, Jones DL (2001) Function and mechanism of organic anion exudation from plant roots. Annu Rev Plant Phys 52:527-560. https://doi.org/10.1146/annurev.arplant52.1.527

Sandre AA, Pina JM, Moraes RM, Furlan CM (2014) Anthocyanins and tannins: is the urban air pollution an elicitor factor? Braz J Bot 37:9-18. https://doi.org/10.1007/s40415-013-0043-0

Sembratowicz I, Rusinek-Prystupa E, Ognik K, Truchliński J (2008) Contents of tannins and oxalic acid in the selected Orest fruits depending on the harvest site. Ann Nat Inst Hyg 59(1):41-46
Silva AF, Barbosa LCA, Silva EAM, Casali VWD, Nascimento EA (2003) Composição química do óleo essencial de Hyptis suaveolens (L.) Poit. (Lamiaceae). Rev Bras Plantas Med 6:1-7

Smolander A, Ketolab RA, Kotiahod T, Kanervaa S, Suominene K, Kitunena V (2006) Volatile monoterpenes in soil atmosphere under birch and conifers: 646 effects on soil $\mathrm{N}$ transformations. Soil Biol Biochem 38:3436-3442

Stefanakis MK, Touloupakis E, Anastasopoulos E, Ghanotakis D, Katerinopoulos HE, Makridis P (2013) Antibacterial activity of EOs from plants of the genus Origanum. Food Control 34:539-546. https://doi.org/10.1016/j.foodcont.2013.05.024

Stevovič S, Čalič-Dragosavac D, Surčinski Mikovilovič V, ZdravkovičKorač S, Milojevič J, Cingel A (2011) Correlation between environment and essential oil production in medicinal plants. Adv Environ Biol 5(2):465-468

Supuka J, Berta F (1998) The composition of terpenes in needles of white pine (Pinus strobus L.) growing in urban environment. Ekólogia (Bratislava) 17(1):102-116

Supuka J, Chladna A, Berta F (1997) The influence of the urban environment on the composition of terpenes in the needles of Black Pine (Pinus nigra Arnold). Trees 11:176-183. https://doi. org/10.1007/PL00009666

Tlustoš P, Száková J, Vysloužilová M, Pavlíková D, Weger J, Javorská $H$ (2007) Variation in the uptake of asrenic, cadmium, lead and zinc by different species of willows Salix spp. grown in contaminated soils. Cent Eur J Biol 2:254-275. https://doi.org/10.2478/ s11535-007-0012-3

Ullah S, Hadi F, Ali N, Khan S (2018) Foliar application of iron (Fe) improved the antioxidant defense and $\mathrm{Cd}$ accumulation potential of Ricinus communis under hydroponic condition. Water Air Soil Pollut 229:284. https://doi.org/10.1007/s11270-018-3948-1

Uraguchi S, Watanabe I, Yoshitomi A, Kiyono M, Kuno K (2006) Characteristics of cadmium accumulation and tolerance in novel Cd-accumulating crops, Avena strigosa and Crotalaria juncea. J Exp Bot 57:2955-2965. https://doi.org/10.1093/jxb/er1056

Vamerali T, Bandiera M, Coletto L, Zanetti F, Dickinson NM, Mosca G (2009) Phytoremediation trials on metal- and arsenic-contaminated pyrite wastes (Torviscosa, Italy). Environ Pollut 157:887894. https://doi.org/10.1016/j.envpol.2008.11.003

Viehweger K (2014) How plants cope with heavy metals. Bot Stud 55:35. https://doi.org/10.1186/1999-3110-55-35

Walker CD, Welch RM (1987) Low molecular weight complexes of zinc and other trace metals in lettuce leaf. J Agric Food Chem 35:721-727

Wang Y, Chen X, Whalen JK, Cao Y, Quan Y, Lu C, Shi Y (2015) Kinetics of inorganic phosphorus release influenced by low molecular weight organic acids in calcareous, neutral and acidis soils. J Plant Nutr Soil Sci 178:555-566. https://doi.org/10.1002/ jpln.201500047

Werner A, Napierała-Filipiak A, Mardarowicz M, Gawdzik J (2004) The effects of heavy metals, content of nutrients and inoculation with myccorrhizal fungi on the level of terpenoids in roots of Pinus sylvestris L. Acta Physiol Plant 26:187-196. https://doi. org/10.1007/s11738-004-0008-9

Younis ME, Tourky SMN, Elsharkawy SEA (2018) Symptomatic parameters of oxidative stress and antioxidant defense system in Phaseolus vulgaris $\mathrm{L}$. in response to copper or cadmium stress. S Afr J Bot 117:207-214. https://doi.org/10.1016/j.sajb.2018.05.019

Zhou XB, Shi WM, Zhang LH (2007) Iron plaque outside roots affects selenite uptake by rice seedlings (Oryza sativa L.) grown in solution culture. Plant Soil 290:17-28. https://doi.org/10.1007/s1110 4-006-9072-9

Publisher's Note Springer Nature remains neutral with regard to jurisdictional claims in published maps and institutional affiliations. 